\title{
Approaching sheep herds origins and the emergence of the wool economy in continental Europe during the Bronze Age
}

\author{
S. Sabatini ${ }^{1}$ (D) S. Bergerbrant ${ }^{1} \cdot$ L. Ø. Brandt ${ }^{2} \cdot$ A. Margaryan $^{3,4} \cdot$ M. E. Allentoft ${ }^{3}$
}

Received: 20 February 2019 / Accepted: 8 May 2019 / Published online: 30 May 2019

(C) The Author(s) 2019

\begin{abstract}
In recent years, extensive archaeological studies have provided us with new knowledge on wool and woollen textile production in continental Europe during the Bronze Age. Concentrations of large numbers of textile tools, and of zooarchaeological evidence suggesting intense sheepherding, hint at specialized centres of wool production during the Bronze Age. The aim of this paper is to discuss whether engagement with this economic activity was facilitated by the introduction of new foreign sheep types, possibly from the Eastern Mediterranean, where well-established wool economies existed, or by using local sheep, or a mixture of local and non-local types. A small-scale genetic pilot study, presented in this paper, primarily aimed at testing the DNA preservation, and thus the genomic potential in Bronze Age sheep remains provides evidence of both mitochondrial haplogroups A and B among Bronze Age sheep in Hungary. This result could hint at sheep herds with mixed origin but further in-depth studies are necessary to address this. We aim to promote scholarly interest in the issue and propose new directions for research on this topic.
\end{abstract}

Keywords Ancient wool $\cdot$ Breeding practices $\cdot$ Textile production $\cdot$ Ancient DNA $\cdot$ Second millennium BC

\section{Introduction}

The introduction of wool and of woollen textile production represented in all likelihood a major innovation in Bronze Age Europe during the 2nd millennium BCE. Wool was clearly becoming increasingly appreciated and widespread in Europe. This is demonstrated by the presence of woollen textile fragments in the archaeological record from various parts of the continent (see below). Despite the need for more data to better understand the characteristics of the continental wool economy, current research suggests that local production of wool and woollen products emerged and developed in Europe

S. Sabatini

serena.sabatini@archaeology.gu.se

1 Department of Historical Studies, University of Gothenburg, Box 200, 40530 Gothenburg, Sweden

2 Centre for Urban Network Evolutions, Aarhus University, Moesgård Allé 20, 8270 Højbjerg, Denmark

3 Lundbeck Foundation GeoGenetics Centre, Department of Biology, University of Copenhagen, Øster Voldgade 5-7, Copenhagen 1350, Denmark

4 Institute of Molecular Biology, National Academy of Sciences, 7, Hasratian St., 0014 Yerevan, Armenia during the Bronze Age (e.g. Becker et al. 2016; Bergerbrant 2018; Bergerbrant in press; Gleba 2017; Sabatini et al. 2018; Vretemark 2010). Moreover, recent strontium isotope analyses on wool textiles from the Early Bronze Age in Denmark suggest that the clothing found in a number of local elite graves was manufactured mainly with wool produced outside present-day Danish territory, the island of Bornholm excluded (Frei et al. 2015; Frei et al. 2017; see Thomsen and Andreasen 2019 for baseline discussion). These results show the existence of a continental trade of wool and/or of woollen textiles on a large scale (Kristiansen and Sørensen in Press).

Multiple factors must have contributed to this rise of continental wool economies, including technological exchange and a growing demand (e.g. Bender Jørgensen 2018; Frei et al. 2017; Harris 2012; Kristiansen 2016). However, the emergence of local production might have been triggered, or facilitated, in the first place by access to woollier animals. This could have happened through the introduction of new foreign animals or by extensive breeding in local sheep or maybe a mixture of both. To understand the development of the wool economy, it is therefore of critical importance to identify the type of sheep used for production. Supported by the results of our small-scale genetic study (see below), we argue that an interdisciplinary approach is essential to addressing this problem, and valuable insights are expected to come in the future through the study of ancient DNA (aDNA) from sheep. 


\section{The emergence of wool production during the European Bronze Age}

A wealth of archaeological evidence has shown that woollen textiles came into use across continental Europe at the onset of the second millennium BCE (Bender Jørgensen 1992; Bender Jørgensen and Rast-Eicher 2016; Bender Jørgensen and RastEicher 2018; Gleba and Mannering 2012; Rast-Eicher and Bender Jørgensen 2013), and also that a local production emerged at some sites throughout the following centuries (Belanová Štolcova and Grömer 2010; Bergerbrant 2018; Bergerbrant in press; Earle and Kristiansen 2010b; Sabatini et al. 2018). Fully developed wool economies already existed in the Near East during the third millennium BCE as documented by archaeological, iconographical and written sources (e.g. Biga 2011; Breniquet and Michel 2014; Michel and Nosch 2010; Wisti Lassen 2010). A comparable combination of evidence shows that wool and woollen textile production also flourished in the Aegean during the second millennium BCE (e.g. Burke 2012; Del Freo et al. 2010; Killien 2015; Nosch 2014; Nosch 2015). Around the coasts of the northeastern Mediterranean, the wool economy appears to have been an expansive activity involving large numbers of animals, intense labour, specialised artisans and meticulous administration. However, it is clear that written archive records from these areas represent a major source of information and we could not have gained such insights by relying only on archaeological evidence (see e.g. Burke 2012; Siennicka 2014; Skals et al. 2015; Tournavitou et al. 2015).

For the study of wool economy in the continental context, textual and archaeological evidence from the Mediterranean world, although politically and socio-culturally different, represent important contemporaneous references (Sabatini 2018). However, when lacking written sources, we must rely on three kinds of archaeological evidence to assess wool production in Bronze Age Europe: (1) the occurrence and distribution of tools related to the production of textiles, (2) the zooarchaeological remains revealing the presence of high proportions of sheep/goats among the domesticated animals, and (3) the presence of fragments of wool textiles. Textile tools attest to the production of textiles (e.g. Barber 1991; Gleba 2008), but how these can be used to assess the quality, type and origin of the fibres has been much debated (e.g. Andersson Strand et al. 2008; Andersson Strand and Nosch In press; Grömer 2006; Kania 2015). Zooarchaeological studies, in combination with the study of the archaeobotanical remains, are critical to our understanding of whether there was access to wool or plant fibres or both (e.g. Barber 1991; Bender Jørgensen 2018). A significant number of different textile tools and high percentages of sheep/goat among the faunal remains was recently demonstrated at the Hungarian Middle Bronze Age (c. 2000-1500/1400 BCE) site of Százhalombatta-Földvár (Bergerbrant 2018; Vretemark
2010) and at the Italian Middle and Recent Bronze Age (c. 1550-1200 BCE) Terramare settlement of Montale in the Po valley (De Grossi Mazzorin and Ruggini 2009; Sabatini et al. 2018). The characteristics of the local material suggest that both sites might have been centres of specialized wool manufacture, producing exports in exchange for locally unavailable raw materials such as metals.

We sampled sheep teeth from both areas to carry out a small-scale genetic pilot study (see below). The aim of the study was first and foremost to test the DNA preservation and thus assess the potential for a larger population genetic study, but also to hint at eventual genetic differences, similarities and possible links in the sheep between these two specific areas. For this last specific purpose, animal remains dated to about the same time (approximately sixteenth-fifteenth century $\mathrm{BCE})$ were chosen.

\section{Bronze Age wool and wool textiles from continental Europe}

Extensive studies of textile tools and bone assemblages combined with investigations of the environmental conditions that have allowed for the survival and preservation of a significant number of Bronze Age woollen fabrics and clothing have provided us with an increasingly detailed understanding of the continental wool production. These remains are scattered both geographically and chronologically, but can provide precious insights into local spinning and weaving traditions (e.g. Bender Jørgensen 1992; Gleba 2017). Some of the most famous European Bronze Age woollen textiles are represented by the oak-log coffins excavated in Denmark (Bergerbrant 2007; Broholm and Hald 1940), generally dated between the end of the 15th and the thirteenth century BCE (Holst et al. 2001). Another important collection of woollen textiles has been retrieved from the Hallstatt salt mines in present-day Austria, dated between the fifteenth and twelfth century BCE (Grömer 2012; Grömer 2016; Grömer et al. 2013). A large (at least $300 \times 170 \mathrm{~cm}$ ) piece of cloth was also found in Pustopolje in Bosnia-Herzegovina (Bender Jørgensen and Grömer 2013; Grömer et al. 2018; Harding 1995; Marić Baković and Car 2014), radiocarbon dated to $3195 \pm 30$ BP (Marić Baković and Car 2014), or 1517-1414 BCE (2 sigma, calibrated with Oxcal v4 3,2 (Bronk Ramsey 2009)). A few sites in Italy (Bazzanella 2012; Gleba 2008; Gleba 2012) and a limited number of other European areas (Bender Jørgensen and Rast-Eicher 2015; database 2013; Gleba and Mannering 2012) complete the picture. Despite the lack of written records, there is sparse but significant evidence for the use of woollen textiles starting from the second millennium BCE. A recent study (Gleba 2017) argued for a continental textile tradition that produced fabrics that are different from those of the Mediterranean region, thus indirectly supporting our hypothesis of a continent-based production (see also Sabatini 2018). 
However, due to the estimated limited annual wool yield per sheep per year (see discussion below), in order to have an economically sustainable wool production during the Bronze Age, it was necessary to have access to large numbers of woolly-fleeced sheep. We believe that the characteristics of sheep and sheep fleeces had a determinant role in relation to the emergence of local wool economies. Therefore, the study of sheep evolution is of utmost importance for understanding the political economy of the continent during the Bronze Age.

\section{Scientific approaches to the study of prehistoric sheep and wool}

In addition to the information offered by Aegean and Near Eastern written sources, the study of prehistoric sheep has often been pursued within two main spheres: textile archaeology (e.g. Bender Jørgensen 1992; Breniquet and Michel 2014; Ryder 1983) and zooarchaeology (e.g. Becker et al. 2016; Benecke 1994; Greenfield 2014). In recent times, new possibilities for investigating prehistoric sheep have become available, thanks to advances in aDNA analyses (Brandt 2014; Niemi et al. 2013; O'Sullivan et al. 2016; Olivieri et al. 2012; Rannamäe et al. 2016a; Rannamäe et al. 2016b). We here present and discuss some of the main results from each of these disciplines relating to the study of sheep and sheep fleece.

\section{Textile archaeology and fibre analysis}

Through textile archaeology, and in particular the study of prehistoric textiles, an interest in the characteristics of early sheep/goat has emerged. One of the main goals for textile archaeologists has often been to obtain a better understanding of the characteristics and quality of the fibres used in the textiles. Important and eagerly debated results concerning these early fibres have been achieved using scanning electron microscopy (SEM) (Gleba 2012; Rast-Eicher 2016; Ryder 1969; Ryder 1988; Skals et al. 2018). Such fibre analyses can provide information on the source of a fibre, vegetable or animal, and assist in identifying the species (Rast-Eicher 2016). Most analysed Bronze Age fibres are from sheep wool (Gleba 2012; Rast-Eicher and Bender Jørgensen 2013) or from plant material, in particular flax (Bazzanella et al. 2003; database 2013). The use of goat hair is known (e.g. Barber 1991; Bender Jørgensen and Rast-Eicher 2018; Del Freo et al. 2010; Frangipane et al. 2009), but to our knowledge, there are no published examples of goat hair fibres from the European Bronze Age (Rast-Eicher 2016). Goat skin, however, has been identified in both Neolithic and Chalcolithic contexts (Hollemeyer et al. 2012; O'Sullivan et al. 2016; Rast-Eicher 2012). Fibre analyses have also demonstrated how fleeces have developed over time (e.g. Gleba
2012; Rast-Eicher and Bender Jørgensen 2013; Ryder 1983), although there are inherent problems in discussing fleece qualities based on ancient textile remains, and some studies have reached contradictory conclusions (e.g. Gleba 2012; RastEicher and Bender Jørgensen 2013; see also Skals et al. 2018). One consistent problem may be linked to the fact, documented by ancient written sources from Mesopotamia, that before spinning the yarn, the fleeces were sorted, and likely mixed, to obtain the required wool quality (e.g. Andersson Strand and Cybulska 2013; Waetzoldt 1972).

The challenging aspects of fibre analyses were exemplified recently during the reconstruction work of an Early Nordic Bronze Age cloak (Hammarlund and Bergerbrant Manuscript). The fibre analyses (SEM) carried out on the unworked fleece demonstrated a fibre composition closely resembling compositions found in Bronze Age textiles (Rast-Eicher 2013). However, analyses of the same fleece, but using yarn prepared and spun in different ways, yielded results that for the most part were comparable in character to those obtained when analysing textiles from Iron Age contexts (Hammarlund and Bergerbrant Manuscript; Rast-Eicher 2013). The distinct preparation and spinning methods produced spun fibre of very different quality from categories B to $\mathrm{F}$ in the classification proposed by Rast-Eicher (Rast-Eicher 2013). Fibre analyses provide a wealth of precious information about the applied textile technology (see Rast-Eicher 2016; Skals in Press), but it remains unresolved whether it is possible to use such an approach to discriminate between various types of fleece and to discuss fleece quality and/or the development of it (cf. Skals et al. 2018).

\section{Zooarchaeology}

In contrast to textile archaeology and fibre analyses, zooarchaeology is concerned with the study of animal bones in multifarious ways. While zooarchaeological studies cannot offer data as to the quality and characteristics of prehistoric sheep fleece, they do provide detailed insights into the physical characteristics of the animals, and have been widely used to investigate the development and breeding of sheep through time (e.g. Benecke 1994; Bökönyi 1974; Ryder 1983). Morphological studies of central European faunal assemblages from the Neolithic to the Early Bronze Age show for instance that there was a large variety in sheep sizes and that some regional differences existed (Bökönyi 1974; Grömer and Saliari 2018; Pipes et al. 2014; Schmölcke et al. 2018). Although such data cannot provide information as to the eventual variety of sheep fleeces, it suggests that different types of sheep were already present in the area at the end of the third millennium BCE.

In relation to wool production and textile manufacture, one of the most prominent achievements of zooarchaeological studies derives from the analysis of slaughtering patterns. It 
has been demonstrated that difference in the prevailing slaughtering age can indicate the primary economic role of sheep at a given site (Greenfield 2014; Payne 1973). For example, the fact that older wethers normally produce the most wool (Barber 1991) suggests their presence in a herd could be a sign of wool production. Ancient written texts from the Mediterranean Bronze Age (e.g. Barber 1991; Del Freo et al. 2010; Killen 1964) show that local economies were well aware of the amount of wool that one could obtain from different categories of sheep and that such specialized herds existed. Nevertheless, a mixed economy, exploiting other products in addition to wool, seems the most common practice, which makes it difficult to draw definitive conclusions about the wool economy based solely on zooarchaeological data (see Halstead 1998; Payne 1973).

Zooarchaeological analyses also hold the possibility of estimating the relative proportion of sheep and goat bones in an assemblage. Although not in equal proportions, there is clear evidence that the two species often coexisted in the same managed herd (see e.g. Becker et al. 2016; De Grossi Mazzorin 2013; De Grossi Mazzorin and Ruggini 2009; Greenfield 2005). Since goat hair has not yet been detected in Bronze Age textiles from European mainland, the presence of goats represents an important feature to factor in when discussing wool production, since a significant number of animals may not have been kept for wool. We are confronted by two major difficulties when attempting to estimate the ratio between these two taxa based on the old excavated bones. In general, the taxonomic representation in faunal assemblages may be biased and therefore not directly display the relative proportions of the species as they appeared in a given prehistoric landscape (e.g. Albarella 2017; see also Allentoft et al. 2010). Moreover, it can be very difficult to distinguish sheep from goat osteologically, unless there is access to the diagnostic bones, of which there are only a few (Gillis et al. 2011; Halstead et al. 2002; Salvagno and Albarella 2017). When these particular bones are missing one talks about sheep/goats. Today, due to the discovery of a type 1 collagen peptide with a differing sequence between sheep and goat, the two species can be easily distinguished based on their peptide mass fingerprints (PMF) (Buckley et al. 2010; Campana et al. 2013). This technology is also often referred to as ZooMS (Zooarchaeology by Mass Spectrometry) (see Buckley et al. 2009). Ancient DNA technology (as discussed below) offers another means to distinguish between the two species.

Despite these caveats, a growing volume of zooarchaeological evidence suggests that some major economic changes occurred at the beginning of the second millennium BCE in southeastern Europe. Culling strategies, and thus likely secondary product exploitation patterns, seem to undergo a significant transformation (Becker et al. 2016; Bökönyi 1974; Greenfield 2005; Vretemark 2010), which suggests that wool was becoming an appreciated product. A thorough investigation of the factors that facilitated these changes should be a priority for future research. It is here argued that the introduction of new sheep, possibly with woollier fleeces, would fit well with the archaeological evidence showing the emergence of a continental wool production at this time. Of course, changes in sheep fleece may also have occurred due to changes in local breeding practices. Indeed, according to Ryder (Ryder 1983), the morphological changes (from size decrease, to alteration of the shape of the horns, to development of lighter fleece) seen in sheep during prehistory could be due to both domestication and breeding.

\section{Genetic studies}

Genetic research has great potential to detect changes in the population structure in space and time within any given species. Genetic population studies of sheep have so far had a main focus on modern sheep, and in particular on analyses of their mitochondrial DNA (mtDNA), revealing a great complexity and intense breeding throughout history (Alberto et al. 2018; Fernández et al. 2006; Guo et al. 2005; Hiendleder et al. 1998a; Hiendleder et al. 1998b; Larson et al. 2007; Larson et al. 2005; Luikart et al. 2001; Meadows et al. 2007; Pedrosa et al. 2005; Tapio et al. 2006; Wood and Phua 1996). Recently, analyses of mtDNA have been conducted on prehistoric sheep bone samples as well (Demirci et al. 2013; Niemi et al. 2013; O'Sullivan et al. 2016; Olivieri et al. 2012; Rannamäe et al. 2016a; Rannamäe et al. 2016b), confirming that breeding was commonly practised in early times.

Analysis of archaeological wool has also been attempted with success for mtDNA, but is dependent on treatment processes and environment (Brandt et al. 2011; Sinding et al. 2017). Nuclear DNA has not yet been successfully retrieved from ancient textiles. This may be due to a low amount of nuclear DNA in hair, combined with a more rapid degradation compared to mtDNA. Next-generation sequencing technology will hopefully change this in the future (Brandt and Allentoft in Press). Given the increasing possibility of working on highly degraded aDNA, we anticipate many insights into the ancient sheep gene pools in the future. Ancient DNA provides information on the genetic diversity of ancient populations (e.g. Allentoft et al. 2015; Larson et al. 2007; Larson et al. 2005) but in order to properly understand migratory patterns (whether artificially moved around by humans or by natural events) and detect changes in the gene pool, one preferably needs access to a broad reference database. The number of published mtDNA sequences from ancient sheep is still limited and further studies are therefore required to document genetic changes in the past (Brandt and Allentoft in Press). For instance, according to Brandt and Allentoft (Brandt and Allentoft in Press) one should consider that there might be a number of mtDNA haplogroups that have disappeared with 
time and which cannot be detected when only investigating modern sheep populations.

Additionally, while mtDNA and Y-chromosome studies may help us trace back the lineages of specific sheep, they cannot provide information on the sheep's appearance such as the nature of the fibres and the coat colour, which must have had crucial significance in the breeding practices. For this, we need knowledge on specific genes, which, for example, can be obtained by sequencing the complete genomes of the animals. So far, there have only been a few studies that can help us on the way. Though research on modern sheep (Seroussi et al. 2017), suggested candidate genes for affecting fibre diameter (KATNAll) and coat pigmentation $(F R Y)$. In the future, when more studies have confirmed these genetic influences in modern sheep, we can potentially investigate the same gene sequences in ancient sheep, before and after various key events related to domestication and wool production. This will allow us to gain a much deeper understanding of the relationships between the evolution and domestication of sheep, their fleece, and eventually of textile production.

\section{Domestication and spread of sheep}

Much literature is available on issues of domestication and the early exploitation of secondary products (e.g. Becker et al. 2016; Benecke 1994; Demirci et al. 2013; Greenfield 2010; Greenfield 2014; Larson and Burger 2013; Lawson Handley et al. 2007; Legge 1996; Marciniak 2011; Sherratt 1981; Sherratt 1983; Wang et al. 2015). Sheep/goats were probably initially domesticated for meat consumption and eventually their skin and milk became valuable too. Throughout the Neolithic period all over Eurasia, with possible exceptions (Grabundžija and Russo 2016; Pipes et al. 2014; Shislina et al. 2003), there is no conclusive evidence for the use of wool (e.g. Barber 1991; Greenfield 2010; Marciniak 2011) in textile production, while both sheep and goat skins were clearly exploited for clothing (Hollemeyer et al. 2012; O’Sullivan et al. 2016; Rast-Eicher 2012).

It is believed that sheep were domesticated from wild Mouflon (Ovis orientalis), or rather a minimum of three ancestral sub-species of the wild Mouflon (Lawson Handley et al. 2007; Ryder 1983). Later analyses have suggested that the European Mouflon is a remnant after an early domestication event, so more investigations are needed before understanding the relationship between the Asian Mouflon and our current domesticated sheep (Meadows et al. 2011). Sheep were probably initially domesticated in the 10th millennium BCE (Alberto et al. 2018; Demirci et al. 2013; Hole 1996; Larson and Fuller 2014; Legge 1996; Naderi et al. 2008; Zeder 2012), but Meadows (Meadows et al. 2011) argues that the domestication must have occurred through at least five domestication processes. Goats seem to have been preferred over sheep on some of the sites with evidence of early domestication in southwest Asia (Legge 1996; Naderi et al. 2008), while other southwest Asian locations demonstrate a dominance of sheep bones (Stiner et al. 2014). The latter focus is typical in Early Neolithic sites in Greece (Halstead 1996) and can also be seen in most of continental Europe during the Bronze Age (e.g. Bartosiewicz 2013; Becker et al. 2016; De Grossi Mazzorin 2013; Greenfield 2005).

While most scholars agree that domestication took place somewhere in southwest Asia, there have been different suggestions as to the routes along which domesticated sheep spread from Asia into Europe. During the Neolithic period (approximately 6th to 4th millennium BCE) domesticated animals spread to the rest of Europe (Bökönyi 1974; Ryder 1983). One suggested route for the spread of the first farmers into continental Europe is via the Danube, and another is a marine route through the Mediterranean Sea (Ryder 1983). Some studies support the hypothesis of a maritime route for the specific case of the Iberian Peninsula (Pereira et al. 2006; Zilhão 2001). The importance of the Danube route for the spread of domesticated sheep into central and northern Europe has been emphasised by Kijas (Kijas et al. 2012). Since aDNA analyses of pig indicate that domesticated pigs spread from Asia via the Danube to central and northern Europe (Larson et al. 2007), we might imagine that domestic caprines were introduced in a similar way. Neolithic sheep/ goats from continental Europe also appear to have been morphologically different (size, presence and shape of the horns) through time and regions, and environmental factors, among other things, possibly affected health and characteristics of the sheep/goat population (Bökönyi 1974; Grömer and Saliari 2018; Pipes et al. 2014). Such factors may have had an impact on the success of different waves of introductions (cf. Gronenborn 2009).

Disregarding the exact route, analyses of endogenous retroviruses $(E R V=$ part of the genome that contains an active or inactive element of a retrovirus (see Brown 2012)) as genetic markers, Chessa et al. (2009) have argued that there must have been two migrations of sheep from the Near East to Europe. Remnants of the first wave of sheep are breeds such as Sardinian and Corsican Mouflons, or Scottish Soay and Nordic short-tailed sheep (Chessa et al. 2009). A second migration of sheep with 'improved production traits' occurred at a non-specified later time. These later sheep are regarded as the antecedents of many modern sheep (Chessa et al. 2009).

\section{Wool, sheep breeding and fleece development}

Today over 1155 local (present only in one country) and 227 transboundary sheep breeds exist in the world (Baumung and Wieczorek 2015). Although the total number has drastically 
increased since the early modern period (Kijas et al. 2012), these figures clearly show how important sheep are for societies across the world. Generally, it is believed that the ancient sheep moulted sometime during the spring and summer months (Ryder 1983) and the wool that was first used was therefore wool that was 'naturally' released by the animals. So-called primitive sheep breeds such the Soay sheep from the St Kilda archipelago in northern Scotland, still moult (Clutton-Brock et al. 2004), but most modern breeds do not moult (Ryder 1983). It is often considered that the appearance of the first iron shears during the first millennium BCE is connected to non-moulting wool-producing sheep (Barber 1991); conversely the invention and use of shears might have made it more feasible to breed sheep that did not moult (e.g. Gleba 2008).

It has been highlighted that according to Mesopotamian written records, clipping was used in the production of goat hair, thus both plucking and clipping were to a certain extent already known practices during the Bronze Age (Barber 1991, p. 29). A need for wool has driven sheep breeding practices all over the world, and even today, there are races such as the Peppin Merino, which can produce an average of c. $10 \mathrm{~kg}$ fine quality wool per animal per year with picks over $18 \mathrm{~kg}$ for specific stud rams (breeders n.d.). However, these numbers are unthinkable for a prehistoric wool economy. Thanks to a body of ancient written sources from the Near Eastern and the Aegean, we have rather precise indications as to quantity and quality of the prehistoric wool production (e.g. Breniquet and Michel 2014; Del Freo et al. 2010). Archive documents from the Aegean show for instance that a general standard weight of a sheep fleece was 700-750 g (e.g. Nosch 2014). Based on preserved ancient texts Killen (Killen 1964) was able to demonstrate in a seminal work that specialized wool-producing sheep flocks existed in Bronze Age Crete and would have been composed of 100 wethers, which were expected to deliver 25 LANA, i.e. $75 \mathrm{~kg}$ or c. $750 \mathrm{~g}$ per animal (see also Del Freo et al. 2010). A mixed herd supposedly consisting of c. 120 sheep, 60 ewes and 60 lambs, was to produce a total of 12 LANA, i.e. about $36 \mathrm{~kg}$ or c. $300 \mathrm{~g}$ per animal (Del Freo et al. 2010); if the latter was calculated only on the ewes then the differences expected between ewes and wethers was c. $600 \mathrm{~g}$ versus $750 \mathrm{~g}$ (Rougemont 2014). Written sources also show that well-documented Bronze Age wool economies in the wider Mediterranean area (including the Near East) relied on a huge number of sheep, up to over 100,000 animals directly owned by the producing institutions. It also seems clear that the sheep were carefully managed into smaller herds assigned to individual shepherds throughout the year (Biga 2014; Firth 2014; Foster 2014; Matoïan and Vita 2014; Rougemont 2014). Finally, Mesopotamian written sources (Andersson Strand 2014: 44) suggest that woollier sheep existed there, and were able to provide a yearly wool yield between 0.7 and $1.12 \mathrm{~kg}$. Thus, sheep breeding attempting to gain woollier sheep was likely to have been commonly practised, and with noteworthy results.

To summarize, sheep/goats are common domesticated animals that have been living close to humans since at least the 10th millennium BCE, when initially they were used for their meat, milk and skin. Interest in sheep wool must have manifested rather early but the first real evidence of wool production is from the 4th millennium BCE in the Mesopotamian region. Early sheep did not have a particularly woolly fleece with staples long enough to allow successful spinning. Our assumption is that in order to be able to produce wool for textile production it is necessary to have access to sheep with a specific type of fleece. A series of events must have led to the woollier fleece and breeding practices would surely have been an essential part of this development. Various disciplines have contributed to our present understanding of the relationship between sheep and sheep fleeces and wool production. Fibre analyses suggest that fleece quality and colour have changed through time. Zooarchaeological assessments have proven that deliberate culling strategies were employed to optimize the production, but also that the morphological characteristics of sheep changed significantly thanks to domestication and breeding practices. Modern DNA studies have confirmed that sheep breeding must have been widespread (Alberto et al. 2018), but whether this involved moving a large number of animals or instead conducting intense targeted breeding on the sheep already present in Europe remains unresolved. It seems that breeding practices aiming to improve specific traits such as woollier fleeces can be successful with the introduction of just one individual/ram with the required characteristics into a given flock (e.g. Munro 2003). In other words, relevant changes could have been implemented by just introducing a small number of animals into the existing herds, followed by heavy breeding among these newcomers.

We believe that it was a change in the sheep population, and in particular of sheep fleeces, that facilitated the rise of the continental wool economies. It is reasonable to expect that access to new sheep with improved productive characteristics (e.g. relating to wool and length/characteristics of the staples) would have a significant economic impact. It is hoped that future DNA analyses can be used to test these hypotheses and allow us to also investigate more quantitative questions regarding the numbers of new animals being imported. Did this concern only specifically selected rams that were introduced into existing populations, or did it involve the translocation of large populations of sheep? Or was it simply the breeding technology and strategy that was adopted in Europe during the Bronze Age, applying this to the existing local populations of sheep rather than introducing new foreign animals? 


\section{Ancient DNA analyses of eight Bronze Age samples from the Po (Italy) and the Danubian (Hungary) plains}

For the aDNA part of this study we sampled eight sheep from two Bronze Age archaeological sites: the Hungarian Middle Bronze Age site of Százhalombatta-Földvár and the Italian Middle and Recent Bronze Age Terramare area in the central part of the Po valley. The overall aim was to assess the DNA preservation in these samples allowing us to evaluate the potential for conducting genome-scale studies of the Bronze Age sheep populations. Species identification of all ancient samples was carried out by experienced archaeologists and a zooarchaeologist.

For aDNA extraction, teeth were taken from different archaeological contexts within the chosen sites to ensure (as far as possible) the sampling of different individuals.

\section{The archaeological context of the samples}

Baggiovara (Modena province) is an early Terramare settlement from the Po plain. It was c. 1 ha in size and was fortified like most of the Terramare settlements. Terramare populations inhabited the central Po plain from the beginning of the Italian Middle Bronze Age until the end of the local Recent Bronze Age, c. 1700/1650-1200/1150 BCE (see Bernabò Brea et al. 1997). At the end of the Recent Bronze Age, this apparently prosperous system collapses for reasons that are widely debated (Cardarelli 2009a; Cremaschi et al. 2006). In contrast to other sites of the Po plain, Baggiovara was occupied for a relatively short period of time between the Italian Middle Bronze Age 1 and 2 or c. 1650-1450 BCE (Cardarelli 2009b; Cardarelli et al. 2013). The site was chosen for sampling due to its very early date in the Terramare context, which would enable the mapping of the first sheep in the area close to Montale from which consistent evidence has been found for intensive sheepherding and textile production during the rest of the Middle Bronze Age (De Grossi Mazzorin and Ruggini 2009; Sabatini et al. 2018).

Százhalombatta-Földvár is a fortified Bronze Age tell settlement strategically placed overlooking a bend of the river Danube (Earle and Kristiansen 2010a; Vicze 2013). The tell site has well-preserved occupation layers between 3 and $6 \mathrm{~m}$ thick and dates between c. 2300 and 1500/1400 BCE (Earle and Kristiansen 2010a; Vicze 2013). It has been seen as strategically located between central Europe and the Mediterranean world (Earle and Kristiansen 2010a). Zooarchaeological studies (Vretemark 2010) of the faunal remains from the site show at the onset of the second millennium BCE a marked shift in composition of livestock (sheep from below $20 \%$ of the examined faunal remains before $2000 \mathrm{BCE}$ rise to over $40 \%$ in the following periods). Slaughtering patterns indicate also a shift from meat production before $2000 \mathrm{BCE}$ (sheep are slaughtered at a young age) to secondary product (wool?) production (many sheep kept to an old age). They therefore confirm, at least for the Hungarian plain, earlier suggestions, according to which the general rise of the number of sheep and their prolonged life-time in Bronze Age Eastern Europe was an indication of wool production (Bökönyi 1974). The teeth (Table 1) analysed in this study derive from ongoing excavations and are all dated to the Classical Koszider Phase of the Vatya Cultural complex dating them to 1500-1400 BCE (Vicze 2013).

\section{aDNA extraction}

The aDNA work was carried out in a special clean-room laboratory at the Centre for GeoGenetics, Natural History Museum of Denmark, according to strict aDNA standards (Gilbert et al. 2005; Willerslev and Cooper 2005). All the samples were mechanically cleaned by removing the surface area with diamond-dust-coated disks. We drilled out between 179 and $305 \mathrm{mg}$ powder from the sheep teeth targeting the cementum-rich layer of the roots (though this is complicated by the folded structure of sheep teeth), which has been demonstrated to contain elevated amounts of endogenous DNA compared to the inner dentine (Damgaard et al. 2015).

Depending on the sample size of the initial material, the bone powder was dissolved in 3-4 $\mathrm{ml}$ of extraction buffer (0.463 M EDTA, $10 \mathrm{mM}$ TE buffer $100 \times, 0.14-0.22 \mathrm{mg} / \mathrm{ml}$ Proteinase K, $0.5 \%$ N-laurylsarcosine (10\%) and 1/1000 vol. Phenol red). For the first 15-20 min, a pre-digestion step was introduced to enrich for endogenous DNA (Damgaard et al. 2015) and this was followed by an overnight incubation at $37{ }^{\circ} \mathrm{C}$ in an identical buffer. The samples were centrifuged and DNA was extracted by incubating the supernatant with a $10 \times$ vol. of binding buffer $(4.88 \mathrm{M} \mathrm{GuHCl}, 29.3 \%$ 2-propanol, $1 / 1000$ vol. phenol red, $24.88 \mathrm{mM} \mathrm{NaCl}, 87.6 \mathrm{mM} \mathrm{Na}$ Acetate (adjusted to $\mathrm{pH} 4.5 \sim)$ ) and $100 \mu \mathrm{l}$ silica beads (prepared as in Rohland and Hofreiter 2007 which was used in: Orlando et al. 2013, 2011) for $1 \mathrm{~h}$. Following DNA-binding, the silica was pelleted by centrifugation and the supernatant removed. The pellet was then first washed with $1 \mathrm{ml}$ of the binding buffer and then twice with $1 \mathrm{ml} 80 \% \mathrm{EtOH}$. After removing the supernatant and letting the pellet dry $(15 \mathrm{~min})$, the pellet was resuspended in $75 \mathrm{ul} \mathrm{TEB}$ buffer (Qiagen EB supplemented with $0.05 \%$ Tween-20) and incubated at $37^{\circ} \mathrm{C}$ for $15 \mathrm{~min}$. The supernatant (the pure DNA extract) was transferred to a new low-bind tube and was used for preparing a DNA library as required for Next Generation Sequencing.

\section{NGS library preparation and sequencing}

DNA extracts ( $20 \mathrm{ul})$ were built into blunt-end DNA libraries using Illumina-specific adapters and NEBNext DNA 
Table 1 The samples from Százhalombatta-Földvár with contextual data from the excavation (courtesy of Magdolona Vicze, Matrica Museum, Százhalombatta, Hungary)

\begin{tabular}{lllll}
\hline Sample & Excavation unit (ID) & Contextual ID & Description of contextual ID & Level \\
\hline LOEB6 & 4247 & ID 4014 & A house in the middle of the excavated area & \\
LOEB7 & 4229 & & & \\
LOEB5 & 4385 & ID 4348 & A debris layer above house with ID 4348 north of house ID 4014 & 11 \\
LOEB8 & 4371 & ID 4213 & Found in the general fill outside a house & 11 \\
\hline
\end{tabular}

Sample Pre Master Mix (E6070) kit according to manufacturer's instructions with some modification (see Margaryan et al. 2017). The DNA libraries were quantified using qPCR and indexed with barcoded primers in subsequent PCR reactions with a sample-dependent number of cycles. The libraries were purified and run on an Agilent Bioanalyzer 2100 to assess DNA concentration and length distribution. The libraries were then pooled (roughly equimolarly) and sequenced at the National Highthroughput DNA Sequencing Centre, University of Copenhagen on one lane on the Illumina HiSeq 2500 platform using $100 \mathrm{bp}$ single-read mode.

\section{DNA data analysis}

To remove the adaptor sequences and stretches of Ns at both ends from the ancient DNA reads we used AdapterRemoval 1.5.2 (Lindgreen 2012). Only DNA sequences with a minimum length of $30 \mathrm{bp}$ were considered for downstream analysis. The trimmed reads were mapped against the sheep mitochondrial reference genome (GenBank: AF010406.1) and whole (GenBank: GCA_000298735.2) reference genomes using BWA 0.6.2 aligner (Li and Durbin 2009) with the seed disabled allowing higher sensitivity (Schubert et al. 2012). Only DNA reads with mapping quality $>30$ were used and sorted using Picard (http://picard.sourceforge.net) and samtools (Li et al. 2009). Duplicate reads at library level were removed by Picard MarkDuplicates (http://picard. sourceforge.net).

The consensus mtDNA sequence for each ancient sample was called using Geneious ${ }^{\circledR}$ v. 9. We considered only sites with a sequencing depth of at least $2 \times$. At each position a base was called only if it was observed in at least $75 \%$ of the reads covering that site.

For compatibility purposes, we also analogously analysed four previously published ancient sheep DNA sequences by O'Sullivan et al. (2016) relevant for this study and previously published modern sheep sequences assigned to haplogroups A, B, C, D, and E (Lancioni et al. 2013; Meadows et al. 2011).

Ancient DNA damage parameters, namely the C/T transition rates (typical for aDNA) (Briggs et al. 2007), were estimated using mapDamage 2.0 (Jonsson et al. 2013).

\section{DNA results}

A total of 164,809,125 DNA reads were generated for all eight ancient samples combined. After mapping our DNA reads to the sheep mitochondrial reference genome (GenBank: AF010406.1), we identified practically no DNA sequences of sheep mitochondrial origin in the case of the four samples from the Italian site Baggiovara. Hence, we did not engage in any further analyses concerning these samples. However, the four samples from Százhalombatta-Földvár (Hungary) contained enough mtDNA sequences (ranging from 517 to 3958 sequences) to yield low coverage mitochondrial genomes with varying depth of coverage ranging from $1.7 \times$ to $14.4 \times$ (Table 2). The average mapped read length ranged from 53.8 to $61.5 \mathrm{bp}$ and this high level of fragmentation is expected for ancient samples (e.g. Allentoft et al. 2012; Lindahl 1993).

The DNA mapping stats against the sheep whole reference genome are presented in the Table 3. The endogenous DNA content for the four ancient samples from SzázhalombattaFöldvár studied in this paper ranged from 0.3 to $9.6 \%$.

The mapped sequences from the four successful samples showed increased $\mathrm{C}$ to $\mathrm{T}$ deamination rates at the $5^{\prime}$ end of sequencing reads compared to the sheep reference mitochondrial genome sequence (Table 2). This observation confirms that the profiled DNA molecules were of ancient origin.

In an attempt to assign mtDNA haplogroup categories (previously observed and published genetic variants) to the four ancient sheep samples from Százhalombatta-Földvár, we constructed a Neighbour Joining tree using previously published sheep mitogenome haplogroup sequences (Lancioni et al. 2013; Meadows et al. 2011; O'Sullivan et al. 2016). The nomenclature of haplogroups is adopted from Lancioni et al. (Lancioni et al. 2013) as also seen in O'Sullivan et al. (2016).

For the two ancient samples LOEB5 and LOEB7 which had the lowest mtDNA coverage, we were only able to reconstruct a partial mitogenome consensus sequence $(52 \%$ and $57 \%$, respectively, see Table 2 ). This restricted the use of these two ancient samples in a combined phylogenetic analysis, and we therefore constructed additional phylogenetic trees for each of these two ancient samples separately.

The results indicate that three (LOEB6, LOEB7, LOEB8) out of four ancient sheep clustered with various 
Table 2 Summary statistics of the analysed samples. The four samples from Baggiovara yielded too few sheep sequences to conduct any meaningful summary statistics. $e$ : mass of tooth material used for DNA extraction, Total: total number of DNA sequences, Retained: number of retained sequences after initial bioinformatical filtering, Mapped: number of sequences that could be mapped to the sheep reference mitochondrial genome, after removing duplicate reads, $D o C$ : Estimated depth of coverage of the mtDNA genome, Length: average length of the mapped sequences, Damage: C-T transition rate at the first nucleotide position of the $5^{\prime}$ end of the reads, Consensus coverage: fraction of the mitochondrial genome with enough DNA reads to call a consensus sequence

\begin{tabular}{|c|c|c|c|c|c|c|c|c|c|}
\hline Sample ID & Museum ID & Mass, mg & Total & Retained & Mapped & DoC & Length, bp & Damage & Coverage \\
\hline LOEB1 & Baggiovara 1 & 305 & $11,218,963$ & $9,460,935$ & 6 & NA & NA & NA & NA \\
\hline LOEB2 & Baggiovara 2 & 179 & $10,593,574$ & $9,765,729$ & 11 & NA & NA & NA & NA \\
\hline LOEB3 & Baggiovara 3 & 286 & $10,200,474$ & $8,961,707$ & 18 & NA & NA & NA & NA \\
\hline LOEB4 & Baggiovara 4 & 231 & $11,926,685$ & $11,106,591$ & 1 & NA & NA & NA & NA \\
\hline LOEB5 & Százhalombatta-Földvár 4385 & 183 & $16,212,838$ & $14,685,010$ & 517 & 1.7 & 55.7 & $27 \%$ & $52 \%$ \\
\hline LOEB6 & Százhalombatta-Földvár 4247 & 259 & $45,390,062$ & $41,143,421$ & 3958 & 14.4 & 60.5 & $32 \%$ & $99 \%$ \\
\hline LOEB7 & Százhalombatta-Földvár 4229 & 202 & $34,902,463$ & $32,128,900$ & 657 & 2.1 & 53.8 & $36 \%$ & $57 \%$ \\
\hline LOEB8 & Százhalombatta-Földvár 4371 & 184 & $24,364,066$ & $21,136,884$ & 2886 & 10.7 & 61.5 & $28 \%$ & $98 \%$ \\
\hline
\end{tabular}

sub-lineages within haplogroup B $(99 \%$ bootstrap support) while LOEB5 belonged within the haplogroup A lineages (Fig. 1) with $100 \%$ bootstrap support for the haplogroup A branch (the separate tree with LOEB7 sample is not shown but again the bootstrap support for a haplogroup B affinity was very high-100\%)).

Similar patterns were observed when using other methods for phylogenetic reconstructions such as Maximum Parsimony or Maximum Likelihood (data not shown). Since the sample LOEB5 had low mtDNA coverage we also used a stricter approach for calling the consensus mtDNA sequence, namely calling a nucleotide only if it was supported by at least 3 reads and observed with $>75 \%$ frequency. This more conservative method resulted in fewer informative but more reliable sites, and again the analysis confirmed the relationship of LOEB5 with haplogroup A with >95\% bootstrap support.

\section{Discussion of the DNA results}

First and foremost, our results have demonstrated that the preservation of aDNA in the sheep teeth from Baggiovara in Italy is very problematic. Based on the methods used here, we can only detect marginal levels of endogenous sheep mtDNA. In contrast, Százhalombatta-Földvár in Hungary seems to constitute a highly promising site for studying the genomics of sheep development. It is well known from human aDNA projects that DNA preservation in warm regions such as the Mediterranean is often highly problematic. The quality of DNA in the samples from Százhalombatta-Földvár however is also rather variable in terms of endogenous DNA content, and it is therefore crucial to apply an initial screening process, in which several-to-many individuals are tested with low coverage shot-gun sequencing before selecting individuals for
Table 3 Sequencing statistics. Shotgun sequencing data of eight ancient sheep samples. Total is the total number of DNA reads per sample. Trimmed is the number of sequences passing quality and length filtering. Mapped represents the number of sequences mapping to the sheep reference genome - GCA_000298735.2, and Final is the same number but with all duplicate sequences removed. Endo\% is the proportion of sequences after trimming that could be identified as sheep, and Duplicates\% shows the proportion of identical reads (clones) in this sheep DNA fraction

\begin{tabular}{|c|c|c|c|c|c|c|}
\hline Sample & Total & Trimmed & Mapped & Final & Duplicates\% & Endo\% \\
\hline LOEB1 & $11,218,963$ & $9,500,192$ & 1905 & 1899 & 0.3 & 0.0 \\
\hline LOEB2 & $10,593,574$ & $9,800,152$ & 5908 & 5901 & 0.1 & 0.1 \\
\hline LOEB3 & $10,200,474$ & $8,997,960$ & 41,672 & 41,259 & 1.0 & 0.5 \\
\hline LOEB4 & $11,926,685$ & $11,143,732$ & 332 & 326 & 1.8 & 0.0 \\
\hline LOEB5 & $16,212,838$ & $14,746,583$ & 125,828 & 113,375 & 9.9 & 0.9 \\
\hline LOEB6 & $45,390,062$ & $41,307,284$ & $3,858,103$ & $3,707,517$ & 3.9 & 9.3 \\
\hline LOEB7 & $34,902,463$ & $32,253,264$ & 110,146 & 101,539 & 7.8 & 0.3 \\
\hline LOEB8 & $24,364,066$ & $21,221,786$ & $2,043,301$ & $1,926,147$ & 5.7 & 9.6 \\
\hline
\end{tabular}


Fig. 1 Neighbour joining tree based on three ancient samples from this study and previously published sheep mitogenomes. The numbers above major branches indicate bootstrap support values. The three ancient samples from this study (LOEB5, LOEB6 and LOEB8) are indicated with rectangular boxes. Ovis vignei mtDNA sequence was used as the outgroup

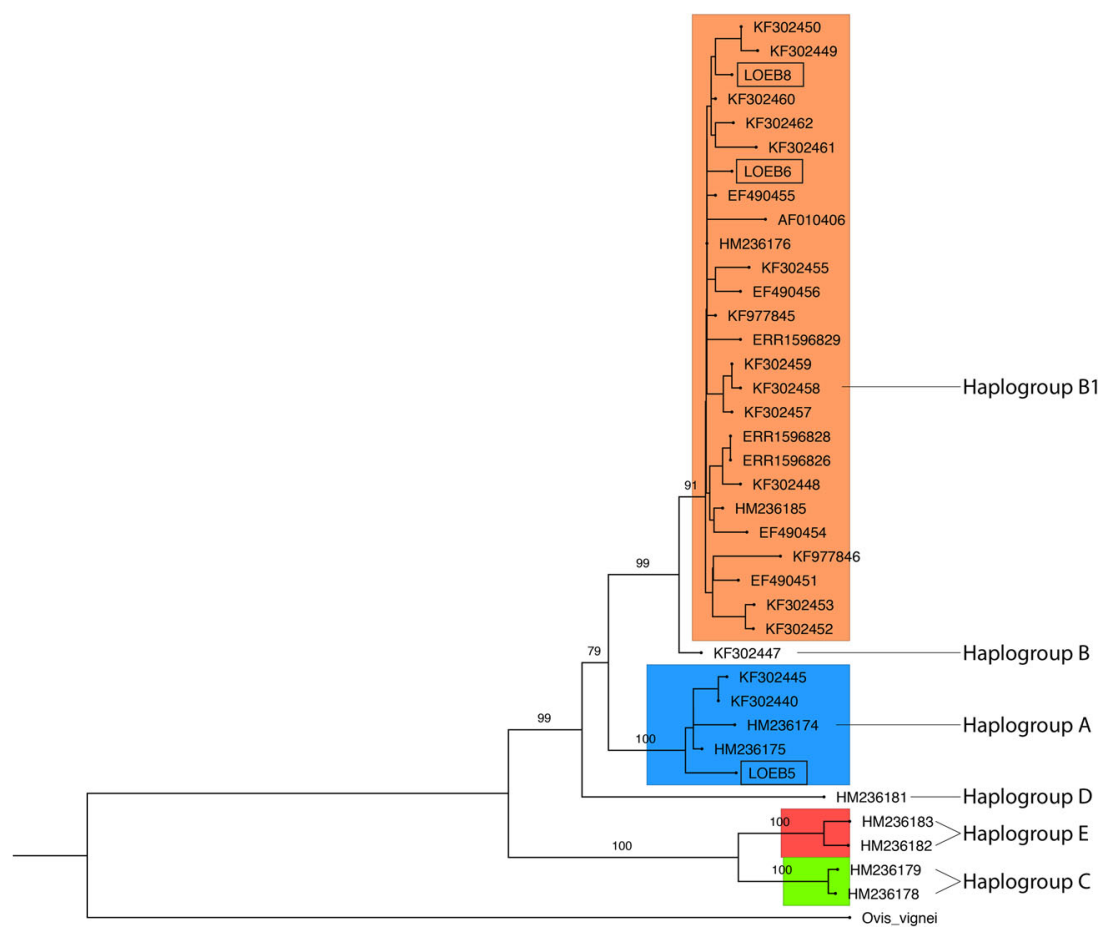

deeper sequencing. Alternatively, full genome or mitogenome capture approaches could be attempted (e.g. Carpenter et al. 2013) in order to minimize sequencing costs of problematic samples. Moreover, petrous bones could be sampled in future aDNA sheep studies, since these have been shown to yield very good DNA preservation in for example humans and horses-and also from 'problematic' regions such as the Mediterranean (Gallego Llorente et al. 2015; Lazaridis et al. 2016; Skoglund et al. 2016).

Prior to this study, only a few analyses of full mitochondrial genomes from sheep have been carried out and also the number of published partial mitochondrial genomes is limited. Previous studies of the mtDNA Control Region and/or the cytochrome $b$ gene of modern domesticated sheep breeds distributed over a wide geographical area have identified five sheep haplogroups A, B, C, D and E (Guo et al. 2005; Hiendleder et al. 2002; Hiendleder et al. 1998b; Meadows et al. 2011; Meadows et al. 2005; Meadows et al. 2007; Pedrosa et al. 2005; Wood and Phua 1996), which have been tentatively proposed to each represent a separate domestication event (Meadows et al. 2011; Pedrosa et al. 2005). Among these, haplogroups A and B are the most frequent ones and have been identified in modern sheep from all sampled geographical regions. Haplogroup A occurs particularly frequently in Asian sheep, whereas haplogroup B dominates in European sheep (Hiendleder et al. 1998b; Wood and Phua 1996). Haplogroup C is less prevalent, but has been located within both Asia, the Fertile Crescent and Europe (Guo et al. 2005; Pedrosa et al. 2005; Pereira et al. 2006; Tapio et al. 2006). Haplogroups D and $E$ are the least frequent and have only been identified in samples from Turkey and the Caucasus (Meadows et al. 2007; Tapio et al. 2006). Sheep haplogroups have also been identified in a number of studies on ancient teeth (Cai et al. 2007) and bone samples (Brandt 2014; Cai et al. 2011; Horsburgh and Rhines 2010; Niemi et al. 2013; Rannamäe et al. 2016a; Rannamäe et al. 2016b).

The earliest samples so far analysed from Europe derive from sheep hair from the skin garments of the Copper Age Iceman Otzi (c. 3350-3120 BCE), who was found extremely well-preserved in a glacier on the border between Austria and Italy in 1991 (Egg and Spindler 2009; O'Sullivan et al. 2016; Olivieri et al. 2012). The permafrozen layer in which the Iceman was preserved provided highly favourable conditions for DNA preservation. O'Sullivan et al. (2016) applied NGS technology to sequence DNA from the samples and managed to assemble three complete and one partial mitochondrial genome (O'Sullivan et al. 2016). All individuals were placed within the sheep mitochondrial haplogroup B, which is dominant in Europe still today. Sheep bones from the Early Neolithic Period and Roman Iron Age of the Danish prehistory also fall within haplogroup B (Brandt 2014). Likewise, the DNA in the sheep wool, from a textile sample from the tenth to fifteenth century CE from Greenland, could also be assigned to haplogroup B (Sinding et al. 2017).

In previous analyses of sheep bone samples from presentday Finland dating to the Iron Age, Medieval, and PostMedieval periods haplogroup B was observed in most instances, whereas haplogroup A was only observed in the medieval and more recent post-medieval samples (Niemi et al. 2013). In sheep samples from present-day Estonia, 
haplogroup A was observed from the Iron Age and Middle Ages, whereas B was observed in the earlier Bronze Age (Rannamäe et al. 2016a). So far it thus seems that haplogroup $\mathrm{B}$ is the oldest in Europe with haplogroup A arriving at a later stage; the oldest traces of haplogroup A have been documented in Asia. Demirci et al. (Demirci et al. 2013) can show the presence of both haplogroups A and B in sheep samples from the site Oylum Höyük in present-day Turkey dating from 1800 BCE. While further east Schröder et al. (2016) demonstrated the presence of both haplogroups A and B in sheep leather clothing from the Wupu cemetery in Xinjiang Uyghur Autonomous Region of north-western China dating to Bronze Age (eighth-sixth century BCE). Haplogroup $\mathrm{C}$ has been found in modern Tsigai sheep in Hungary (Tapio et al. 2006), but not yet in prehistoric samples from Europe. Since the Tsigai sheep is introduced in Hungary during historical periods (Bökönyi 1974), it is possible that haplogroup C was a generally late introduction in the continent.

To our knowledge, our sample LOEB5 is by far the oldest sheep sample in Europe assigned to haplogroup A (c. 1500$1400 \mathrm{BCE})$. This observation is highly interesting as the sample comes from a site that is most likely among the earliest continental centres of wool production that started at the beginning of the second millennium BCE (Vretemark 2010). In the light of these genetic results and the discussion above concerning wool production in Bronze Age Europe, it is worth speculating that the haplogroup A sheep from Százhalombatta-Földvár may represent evidence of new sheep tentatively introduced into Europe during the Bronze Age in order to improve productions traits. We believe that the preliminary results presented here provide an excellent foundation for future genetic research, aimed at examining many more Bronze Age sheep remains from across Europe. This will allow us to understand how the spread of domesticated sheep from different parts of the world could have contributed to the development of woolly fleeces and thus of wool economies in general.

\section{Concluding remarks}

In recent years, extensive archaeological studies have provided us with new knowledge on wool and woollen textile production in continental Europe during the Bronze Age. The discovery of large numbers of textile tools, combined with zooarchaeological evidence suggesting intense sheepherding, has been used to pinpoint specialized centres of wool production during this period. One of the aims of this paper is to propose new directions for research in order to grasp the mechanisms that facilitated Bronze Age societies' engagement in wool economy. We argue that sheep breeding oriented towards improvement of specific productive traits, such as woollier fleeces, must have had a major role in the process.
Our genetic analyses showed a great molecular potential in the sheep remains from Hungary. Moreover, the observation of both haplogroups A and B in this population is highly interesting. This could hint at foreign sheep being imported to improve specific productive traits. In order to generate sufficient data to support such preliminary conclusions, and eventually detect other possible haplogroups as well as of course trying to identify the genes responsible for the characteristics of the wool, it would be necessary to analyse a large sample from both the chronological phases predating any evidence of wool production and phases contemporary with it.

An important direction for future research is therefore to investigate the relationship between the characteristics of local sheep populations and the archaeological evidence for continental wool production. We believe that it is a crucial issue, and that transformations of productive traits in the animal population had great consequences on the economy of those regions/areas that were able to exploit or facilitate the change. We believe that the combined effort between archaeological investigations and aDNA studies will bring fundamental results and greatly enhance our understanding of the Bronze Age political economy in general and the wool economy in particular.

Acknowledgements Sampling of the sheep bones from SzázhalombattaFöldvár (Hungary) and Baggiovara (Italy) was possible thanks to the kind collaboration and support of Magdolona Vicze (Matrica Múzeum, Százhalombatta, Hungary), Andrea Cardarelli (University of Rome La Sapienza, Italy) and Jacopo De Grossi Mazzorin (University of Salento, Italy). We thank Jesper Stenderup (Centre for GeoGenetics, Copenhagen, Denmark) for the technical assistance with the DNA work. We are also grateful to Kristin Bornholdt Collins for assisting with proofreading and language revision.

Funding information This project was supported by the Swedish Foundation for Humanities and Social Sciences under Project Grant P15-0591:1 Bronze Age Wool Economy: Production, trade, environment, herding and society; the Berit Wallenberg Foundation under grant BWS 2014.0083. Provenience analysis of aDNA and strontium isotope in Bronze Age sheep; the Department of Historical Studies, University of Gothenburg, Sweden. The aDNA component of this study was supported by the Villum Foundation, Young Investigator Programme, granted to M.E. Allentoft (grant no. 10120).

Open Access This article is distributed under the terms of the Creative Commons Attribution 4.0 International License (http:// creativecommons.org/licenses/by/4.0/), which permits unrestricted use, distribution, and reproduction in any medium, provided you give appropriate credit to the original author(s) and the source, provide a link to the Creative Commons license, and indicate if changes were made.

\section{References}

Albarella U (2017) Zooarchaeology in the twenty-first century: where we come from, where we are now, and where we are going. In: Albarella U, Rizzetto M, Russ H, Vickers K, Viner-Daniel S (eds) 
The Oxford handbook of zooarchaeology. Oxford University Press, Oxford, pp 3-22

Alberto FJ, Boyer F, Orozco-terWengel P, Streeter I, Servin B, de Villemereuil P, Benjelloun B, Librado P, Biscarini F, Colli L, Barbato M, Zamani W, Alberti A, Engelen S, Stella A, Joost S, Ajmone-Marsan P, Negrini R, Orlando L, Rezaei HR, Naderi S, Clarke L, Flicek P, Wincker P, Coissac E, Kijas J, Tosser-Klopp G, Chikhi A, Bruford MW, Taberlet P, Pompanon F (2018) Convergent genomic signatures of domestication in sheep and goats. Nat Commun 9:813. https://doi.org/10.1038/s41467-018-03206-y

Allentoft ME, Bunce M, Scofield RP, Hale ML, Holdaway RN (2010) Highly skewed sex ratios and biased fossil deposition of moa: ancient DNA provides new insight on New Zealand's extinct megafauna. Quat Sci Rev 29:753-762. https://doi.org/10.1016/j. quascirev.2009.11.022

Allentoft ME, Collins M, Harker D, Haile J, Oskam CL, Hale ML, Campos PF, Samaniego JA, Gilbert MT, Willerslev E, Zhang G, Scofield RP, Holdaway RN, Bunce M (2012) The half-life of DNA in bone: measuring decay kinetics in 158 dated fossils. Proc Biol Sci 279(1748):4724-4733 https://doi.org/10.1098/rspb.2012. 1745

Allentoft ME, Sikora M, Sjögren KG, Rasmussen S, Rasmussen M, Stenderup J, Damgaard PB, Schroeder H, Ahlström T, Vinner L, Malaspinas AS, Margaryan A, Higham T, Chivall D, Lynnerup N, Harvig L, Baron J, Casa PD, Dąbrowski P, Duffy PR, Ebel AV, Epimakhov A, Frei K, Furmanek M, Gralak T, Gromov A, Gronkiewicz S, Grupe G, Hajdu T, Jarysz R, Khartanovich V, Khokhlov A, Kiss V, Koláŕ J, Kriiska A, Lasak I, Longhi C, McGlynn G, Merkevicius A, Merkyte I, Metspalu M, Mkrtchyan R, Moiseyev V, Paja L, Pálfi G, Pokutta D, Pospieszny Ł, Price TD, Saag L, Sablin M, Shishlina N, Smrčka V, Soenov VI, Szeverényi V, Tóth G, Trifanova SV, Varul L, Vicze M, Yepiskoposyan L, Zhitenev V, Orlando L, Sicheritz-Pontén T, Brunak S, Nielsen R, Kristiansen K, Willerslev E (2015) Population genomics of Bronze Age Eurasia. Nature 522:167-172. https://doi.org/10.1038/ nature 14507

Andersson Strand E, Cybulska M (2013) Visualising ancient textiles how to make a textile visible on the basis of an interpretation of an Ur III text. In: Nosch ML, Koefoed H, Andersson Strand E (eds) Textile Production and Consumption in the Ancient Near east: Archaeology, Epigraphy, iconography. Ancient Textiles Series, vol 12. Oxbow Books Ltd, Oxford

Andersson Strand E, Mårtensson L, Nosch ML, Rahmstorf L (2008) New research on Bronze Age textile production. Bulletin of the Institute of Classical Studies 5:171-174

Andersson Strand E, Nosch ML (In press) The wool zone in prehistory and protohistory. In: Sabatini S, Bergerbrant S (eds) The Textile Revolution in Bronze Age Europe. Cambridge University Press, Cambrdige

Barber EW (1991) Prehistoric textiles: the development of cloth in the Neolithic and Bronze Ages with special reference to the Aegean. Princeton Univ. Press, Princeton, N.J

Bartosiewicz L (2013) Animals in Bronze Age Europe. In: Fokkens H, Harding A (eds) The Oxford handbook of the European Bronze Age. Oxford University Press, Oxford, pp 328-347. https://doi. org/10.1093/oxfordhb/9780199572861.013.0018

Baumung R, Wieczorek M (2015) Section B: status and trends of animal genetic resources) In: Scherf BD, Pilling D (eds) The second report on the state of the World's Animal Genetic Resources for Food and Agriculture. FAO commission on genetic resources for food and agriculture assessments, Rome, pp 25-42

Bazzanella M (2012) Italy: Neolithic and Bronze Age. In: Gleba M, Mannering U (eds) Textiles and textile production in Europe from prehistory to AD 400. Ancient Textiles Series, vol 11. Oxbow Books Ltd, Oxford, pp 203-214
Bazzanella M, Mayr A, Moser L, Rast-Eicher A (2003) Textiles: intrecci e tessuti dalla preistoria europea. Provincia autonoma di Trento, Trento

Becker C, Benecke N, Grabundžija A, Küchelmann H-C, Pollock S, Schier W, Schoch C, Schrakamp I, Schütt B, Schumacher M (2016) The textile revolution. Research into the origin and spread of wool production between the near east and central Europe. ETopoi Journal for Ancient Studies Special 6:102-151

Belanová Štolcova T, Grömer K (2010) Loom-weights, spindles and textiles - textile production in Central Europe from the Bronze and Iron Age. In: Andersson Strand E, Gleba M, Mannering U, Munkholt C, Ringgaard M (eds) North European symposium for archaeological textiles X. Ancient Textiles Series, vol 5. Oxbow Books Ltd, Oxford, pp 9-20

Bender Jørgensen L (1992) North European textiles: until AD 1000. Aarhus Univ. Press, Aarhus

Bender Jørgensen L (2018) Textile production. In: Bender Jørgensen L, Sofaer J, Sørensen MLS (eds) Creativity in the Bronze Age: understanding innovation in pottery, textile, and metalwork. Cambridge University Press, Cambridge, pp 67-74

Bender Jørgensen L, Grömer K (2013) The archaeology of textiles recent advances and new methods. Godišnjak Hvratskog Restauratorskog Zavoda 3:91-111

Bender Jørgensen L, Rast-Eicher A (2015) Searching for the earliest wools in Europe. In: Grömer K, Pritchard F (eds) Aspects of the design, production and use of textiles and clothing from the Bronze Age to the Early Modern Era (NESAT XII). Archaeolingua, Budapest, pp 67-72

Bender Jørgensen L, Rast-Eicher A (2016) Innovations in European Bronze Age textiles. Praehistorische Zeitschrif 91(1):68-102. https://doi.org/10.1515/pz-2016-0004

Bender Jørgensen L, Rast-Eicher A (2018) Fibres for Bronze Age textiles. In: Bender Jørgensen L, Sofaer J, Sørensen MLS (eds) Creativity in the bronze age: understanding innovation in pottery, textiles, and metalwork production. Cambridge University Press, Cambridge, pp 25-36

Benecke N (1994) Der Mensch und seine Haustiere: die Geschichte einer jahrtausendealten Beziehung. Theiss, Stuttgart

Bergerbrant S (2007) Bronze Age identities: costume, conflict and contact in Northern Europe 1600-1300 BC. Stockholm Studies in Archaeology, vol 43. Bricoleur Press, Lindome

Bergerbrant S (2018) Creativity and spindle whorls at the Bronze Age tell of Százhalombatta-Földvár, Hungary. In: Bender Jørgensen L, Sofaer J, Sørensen MLS (eds) Creativity in the Bronze Age: understanding innovation in pottery, textiles, and metalwork production. Cambridge University Press, Cambridge, pp 91-98

Bergerbrant S (in press) Wool textiles in the early Nordic Bronze Age: local or traded? In: Sabatini S, Bergerbrant S (eds) The Textile Revolution in Bronze Age Europe. Cambridge University Press, Cambridge

Bernabò Brea M, Cardarelli A, Cremaschi M (eds) (1997) Le Terramare. La più antica civiltà padana. Electra, Milano

Biga MG (2011) La lana nei testi degli Archivi Reali di Ebla (Siria, XXIV sec. a.C.): alcune osservazioni. In: Ascalone E, Peyronel L (eds) Studi italiani di metrologia ed economia del vicino oriente antico dedicati a Nicola Parise in occasione del suo settantesimo compleanno. Herder, Rome, pp 77-92

Biga MG (2014) Some aspects of the wool economy at Ebla. In: Breniquet C, Michel C (eds) Wool economy in the ancient Near East and the Aegean: from the beginnings of sheep husbandry to institutional textile industry. Ancient Textiles Series, vol 17. Oxford Books Ltd, Oxford, pp 139-150

Brandt LØ (2014) Species identification of skins and development of sheep wool: an interdisciplinary study combining textile research, archaeology, and biomolecular methods. University of Copenhagen 
Brandt LØ, Allentoft ME (in Press) Archaeological wool textiles - a window into ancient sheep genetics? In: Sabatini S, Bergerbrant S (eds) The Textile Revolution in Bronze Age Europe. Cambridge University Press, Cambridge

Brandt LØ, Tranekjer LD, Mannering U, Ringgaard M, Frei KM, Willerslev E, Gleba M, Thomas M, Gilbert P (2011) Characterising the potential of sheep wool for ancient DNA analyses. Archaeol Anthropol Sci 3:209-221. https://doi.org/10.1007/ s12520-011-0055-2

Breeders AAosM (n.d.) Evolution of the Australian merino. http:// merinos.com.au/genetics/merino-history/australian-merino. Accessed 28 August 2016

Breniquet C, Michel C (eds) (2014) Wool economy in the ancient Near East and the Aegean, from the beginnings of sheep husbandry to institutional textile industry. Ancient Textiles Series, vol 17. Oxbow Books Ltd, Oxford

Briggs AW, Stenzel U, Johnson PLF, Green RE, Kelso J, Prufer K, Meyer M, Krause J, Ronan MT, Lachmann M, Paabo S (2007) Patterns of damage in genomic DNA sequences from a Neandertal. Proc Natl Acad Sci 104(37):14616-14621. https://doi.org/10.1073/pnas. 0704665104

Broholm HC, Hald M (1940) Costumes of the Bronze Age in Denmark: contributions to the archaeology and textile-history of the Bronze Age. Nyt Nordisk forlag - Arnold Busck, Copenhagen

Bronk Ramsey C (2009) Bayesian analysis of radiocarbon dates. Radiocarbon 51:337-360. https://doi.org/10.1017/ S0033822200033865

Brown T (2012) Introduction to genetics: a molecular approach. Garland Science, New York

Buckley M, Collins M, Thomas-Oates J, Wilson JC (2009) Species identification by analysis of bone collagen using matrix-assisted laser desorption/ionisation time-of-flight mass spectrometry rapid communications in mass spectrometry. RCM 23:3843-3854. https:// doi.org/10.1002/rcm.4316

Buckley M, Whitcher Kansa S, Howard S, Campbell S, Thomas-Oates J, Collins M (2010) Distinguishing between archaeological sheep and goat bones using a single collagen peptide. J Archaeol Sci 37:13-20. https://doi.org/10.1016/j.jas.2009.08.020

Burke B (2012) Textiles. In: Cline EH (ed) The Oxford handbook of the Aegean Bronze Age. Oxford University Press, Oxford, pp 430-442

Bökönyi S (1974) History of domestic mammals in Central and Eastern Europe. Akadémiai Kiadó, Budapest

Cai D-W, Han L, Zhang X-L, Zhou H, Zhu H (2007) DNA analysis of archaeological sheep remains from China. J Archaeol Sci 34:13471355. https://doi.org/10.1016/j.jas.2006.10.020

Cai D, Tang Z, Yu H, Han L, Ren X, Zhao X, Zhu H, Zhou H (2011) Early history of Chinese domestic sheep indicated by ancient DNA analysis of Bronze Age individuals. J Archaeol Sci 38:896-902. https://doi.org/10.1016/j.jas.2010.11.019

Campana MG, Robinson T, Campos PF, Tuross N (2013) Independent confirmation of a diagnostic sheep/goat peptide sequence through DNA analysis and further exploration of its taxonomic utility within the Bovidae. J Archaeol Sci 40:1421-1424. https://doi.org/10.1016/ j.jas.2012.09.007

Cardarelli A (2009a) The collapse of the Terramare culture and growth of new economic and social systems during the Late Bronze Age in Italy. Scienze dell'Antichità 15:449-520

Cardarelli A (2009b) Insediamenti dell'età del bronzo fra Secchia e Reno. Formazione, affermazione e collasso delle Terramare. In: Cardarelli A, Malnati L (eds) Atlante dei beni archeologici della provincia di Modena, vol III. Collina e alta Pianura. All'Insegna del Giglio, Florence, pp 33-58

Cardarelli A, Iaia C, Pellacani G (2013) Modena, loc. Baggiovara, stradello Opera Pia Bianchi. Insediamento dell'età del bronzo. In: Labate D (ed) Notizie degli scavi e delle ricerche archeologiche nel Modenese 2011. Atti e Memorie Deputazione di Storia Patria
Province Modenesi serie XI, vol XXXV. Deputazione di storia patria per le antiche provincie modenesi, Modena, pp 300-301

Carpenter ML, Buenrostro JD, Valdiosera C, Schroeder H, Allentoft ME, Sikora M, Rasmussen M, Gravel S, Guillén S, Nekhrizov G, Leshtakov K, Dimitrova D, Theodossiev N, Pettener D, Luiselli D, Sandoval K, Moreno-Estrada A, Li Y, Wang J, Gilbert MTP, Willerslev E, Greenleaf WJ, Bustamante CD (2013) Pulling out the $1 \%$ : whole-genome capture for the targeted enrichment of ancient DNA sequencing libraries. Am J Hum Genet 93:852-864. https://doi.org/10.1016/j.ajhg.2013.10.002

Chessa B, Pereira F, Arnaud F, Amorim A, Goyache F, Mainland I, Kao RR, Pemberton JM, Beraldi D, Stear MJ, Alberti A, Pittau M, Iannuzzi L, Banabazi MH, Kazwala RR, Zhang YP, Arranz JJ, Ali BA, Wang Z, Uzun M, Dione MM, Olsaker I, Holm LE, Saarma U, Ahmad S, Marzanov N, Eythorsdottir E, Holland MJ, AjmoneMarsan P, Bruford MW, Kantanen J, Spencer TE, Palmarini M (2009) Revealing the history of sheep domestication using retrovirus integrations. Science (New York, NY) 324:532-536. https://doi.org/ 10.1126/science.1170587

Clutton-Brock TH, Pemberton JM, Coulson T, Stevenson IR, MacColl ADC (2004) The sheep of St Kilda. In: Clutton-Brock TH, Pemberton JM (eds) Soay sheep: dynamics and selection in an island population. Cambridge University Press, Cambridge, pp 17-51

Cremaschi M, Pizzi C, Valsecchi V (2006) Management and land use in the terramare and a possible climatic co-factor in their abandonment: the case study of the terramara of Poviglio Santa Rosa (northern Italy). Quat Int 151:87-98

Damgaard PB, Margaryan A, Schroeder H, Orlando L, Willerslev E, Allentoft ME (2015) Improving access to endogenous DNA in ancient bones and teeth. Sci Rep 5:11184. https://doi.org/10.1038/ srep11184

database (2013) CinBa Database of Bronze Age Textiles in Europe. http:// cinba.net/outputs/databases/textiles/. Accessed 30 November 2018

De Grossi Mazzorin J (2013) Considerazioni sullo sfruttamento animale in ambito terramaricolo. In: De Grossi Mazzorin J, Curci A, Giacobini G (eds) Economia e ambiente nell'Italia padana dell'età del bronzo: le indagini bioarcheologiche. Edipuglia, Bari, pp $257-$ 263

De Grossi Mazzorin J, Ruggini C (2009) The archaeozoological analysis. In: Cardarelli A (ed) Guide to the Archaeological Park and Open-Air Museum Terramara Montale. Museo Civico Archeologico Etnologico, Modena, pp 68-69

Del Freo M, Nosch ML, Rougemont F (2010) The terminology of textiles in the linear B tablets, including some considerations on linear A logograms and abbreviations. In: Michel C, Nosch ML (eds) Textile terminologies in the ancient Near East and Mediterranean from the third to the first millennia BC. Ancient Textiles Series, vol 8. Oxbow Books Ltd, Oxford, pp 338-373

Demirci S, Koban Baștanlar E, Dağtaș ND, Pișkin E, Engin A, Özer F, Yüncü E, Doğan ŞA, Togan İ (2013) Mitochondrial DNA diversity of modern, ancient and wild sheep (Ovis gmelinii anatolica) from Turkey: new insights on the evolutionary history of sheep. PLoS One 8:e81952. https://doi.org/10.1371/journal.pone.0081952

Earle TK, Kristiansen K (2010a) Introduction: theory and practice in the late prehistory of Europe. In: Earle TK, Kristiansen K (eds) Organizing Bronze Age societies: the Mediterranean, Central Europe, and Scandinavia compared. Cambridge University Press, Cambridge, pp 1-33

Earle TK, Kristiansen K (eds) (2010b) Organizing Bronze age societies: the Mediterranean, Central Europe, and Scandinavia compared. Cambridge University Press, Cambridge

Egg M, Spindler K (2009) Kleidung und Ausrüstung der kuperzeitlichen Gletschermumie aus den Ötztaler Alpen. Römisch-Germanisches Zentralmuseum, Mainz

Fernández H, Hughes S, Vigne JD, Helmer D, Hodgins G, Miquel C, Hänni C, Luikart G, Taberlet P (2006) Divergent mtDNA lineages of 
goats in an Early Neolithic site, far from the initial domestication areas. Proc Natl Acad Sci 103(42):15375-15379. https://doi.org/10. 1073/pnas.0602753103

Firth R (2014) Considering the population statistics of the sheep listed in the East-West corridor Archive at Knossos. In: Nakassis D, Gulizio J, James SA (eds) KE-RA-ME-JA studies presented to Cynthia W. Shelmerdine. INSTAP Academic Press, Philadelphia, pp 293-304

Foster BR (2014) Wool in the economy of Sargonic Mesopotamia. In: Breniquet C, Michel C (eds) Wool economy in the ancient Near East and the Aegean: from the beginnings of sheep husbandry to institutional textile industry. Ancient Textiles Series, vol 17. Oxbow Books Ltd, Oxford, pp 115-123

Frangipane M, Andersson Strand E, Laurito R, Möller-Wiering S, Nosch ML, Rast-Eicher A, Wisti Lassen A (2009) Arslantepe, Malatya (Turkey): textiles, tools and imprints of fabrics from the 4th to the 2nd millennium BCE. Paléorient 35:5-29. https://doi.org/10.3406/ paleo.2009.5275

Frei KM, Mannering U, Kristiansen K, Allentoft ME, Wilson AS, Skals I, Tridico S, Louise Nosch M, Willerslev E, Clarke L, Frei R (2015) Tracing the dynamic life story of a Bronze Age Female. Scientific Reports 5:10431. https://doi.org/10.1038/srep10431

Frei KM, Mannering U, Vanden Berghe I, Kristiansen K (2017) Bronze Age wool: provenance and dye investigations of Danish textiles. Antiquity 91:640-654. https://doi.org/10.15184/aqy.2017.64

Gallego Llorente M, Jones ER, Eriksson A, Siska V, Arthur KW, Arthur JW, Curtis MC, Stock JT, Coltorti M, Pieruccini P, Stretton S, Brock F, Higham T, Park Y, Hofreiter M, Bradley DG, Bhak J, Pinhasi R, Manica A (2015) Ancient Ethiopian genome reveals extensive Eurasian admixture in eastern Africa. Science (New York, NY) 350:820-822. https://doi.org/10.1126/science.aad2879

Gilbert MTP, Bandelt H-J, Hofreiter M, Barnes I (2005) Assessing ancient DNA studies. Trends Ecol Evol 20:541-544. https://doi.org/ 10.1016/j.tree.2005.07.005

Gillis R, Chaix L, Vigne J-D (2011) An assessment of morphological criteria for discriminating sheep and goat mandibles on a large prehistoric archaeological assemblage (Kerma, Sudan). J Archaeol Sci 38:2324-2339. https://doi.org/10.1016/j.jas.2011.04.012

Gleba M (2012) From textiles to sheep: investigating wool fibre development in pre-Roman Italy using scanning electron microscopy (SEM). J Archaeol Sci 39:3643-3661. https://doi.org/10.1016/j.jas. 2012.06.021

Gleba M (2017) Tracing textile cultures of Italy and Greece in the early first millennium BC. Antiquity 91:1205-1222. https://doi.org/10. 15184/aqy.2017.144

Gleba M, Mannering U (eds) (2012) Textiles and textile production in Europe: from prehistory to AD 400. Ancient Textiles Series, vol 11. Oxbow Books Ltd, Oxford

Grabundžija A, Russo E (2016) Tools tell tales - climate trends changing threads in the prehistoric Pannonian Plain. Documenta Praehistorica XLIII:301-326

Greenfield HJ (2005) A reconsideration of the secondary products revolution in southeastern Europe, on the origins and use of domesticated animals for milk, wool, and traction in the Central Balkans. In: Mulville J, Outram A (eds) Zooarchaeology of fats, oils, Milk and dairying. Proceedings of the 9th ICAZ Conference, Durham 2002. Oxbow Books Ltd, Oxford, pp 14-31

Greenfield HJ (2010) The secondary products revolution: the past, the present and the future. World Archaeology 42:29-54. https://doi. org/10.1080/00438240903429722

Greenfield HJ (ed) (2014) Animal secondary products: archaeological perspective on Domesticat Animal Explotation in the Neolithic and Bronze Age. Oxbow Books Ltd, Oxford

Gronenborn D (2009) Climate fluctuations and trajectories to complexity in the Neolithic: towards a theory. Documenta Praehistorica XXXVI:97-110
Grömer K (2006) Textilien der Bronzezeit in Mitteleuropa. Archaeologia Austriaca 90:31-72

Grömer K (2012) Austria: Bronze and Iron Age. In: Gleba M, Mannering $\mathrm{U}$ (eds) Textiles and textile production in Europe from prehistory to AD 400. Ancient Textile Series, vol 11. Oxbow Books Ltd, Oxford, pp 27-88

Grömer K (2016) The art of prehistoric textile making: the development of craft traditions and clothing in Central Europe. Natural History Museum Vienna, Vienna

Grömer K, Jørgensen LB, Baković MM (2018) Missing link: an early wool textile from Pustopolje in Bosnia and Herzegovina. Antiquity 92:351-367. https://doi.org/10.15184/aqy.2018.18

Grömer K, Kern A, Reschreiter H, Rösel-Mautendorfer H (eds) (2013) Textiles from Hallstatt: weaving culture in Bronze Age and Iron Age salt mines = Textilien Aus Hallstatt: Gewebte Kultur aus dem bronze- und eisenzeitlichen Salzbergwerk. Archaeolingua Alapítvány, Budapest

Grömer K, Saliari K (2018) Dressing central European prehistory - the sheep's contribution. An interdisciplinary study about archaeological textile finds and archaeozoology. Annalen des Naturhistorischen Museums in Wien 120:127-156

Guo J, du LX, Ma YH, Guan WJ, Li HB, Zhao QJ, Li X, Rao SQ (2005) A novel maternal lineage revealed in sheep (Ovis aries). Anim Genet 36:331-336. https://doi.org/10.1111/j.1365-2052.2005.01310.x

Halstead P (1996) The development of agriculture and pastoralism in Greece: when, how and what. In: Harris DR (ed) The origins and spread of agriculture and pastoralism in Eurasia. UCL Press, London, pp 296-309

Halstead P (1998) Mortality models and milking: problems of uniformitarianism, optimality and equifinality reconsidered. Anthropozoologica 27:3-20

Halstead P, Collins P, Isaakidou V (2002) Sorting the sheep from the goats: morphological distinctions between the mandibles and mandibular teeth of AdultOvis and Capra. J Archaeol Sci 29:545-553. https://doi.org/10.1006/jasc.2001.0777

Hammarlund L, Bergerbrant S (Manuscript) Fiber and fleece qualities, knowledge gains from a reconstruction of a Bronze Age cloak

Harding A (1995) The finds from Pustopolje tumulus 16 and their European Context. Eirene XXXI:112-119

Harris S (2012) From the parochial to the universal: comparing cloth cultures in the Bronze Age. Eur J Archaeol 15:61-97. https://doi. org/10.1179/1461957112Y.0000000006

Hiendleder S, Kaupe B, Wassmuth R, Janke A (2002) Molecular analysis of wild and domestic sheep questions current nomenclature and provides evidence for domestication from two different subspecies. Proceedings Biological sciences 269:893-904. https://doi.org/10. 1098/rspb.2002.1975

Hiendleder S, Lewalski H, Wassmuth R, Janke A (1998a) The complete mitochondrial DNA sequence of the domestic sheep (Ovis aries) and comparison with the other major ovine haplotype. J Mol Evol 47: 441-448 https://doi.org/10.1007/PL00006401

Hiendleder S, Mainz K, Plante Y, Lewalski H (1998b) Analysis of mitochondrial DNA indicates that domestic sheep are derived from two different ancestral maternal sources: no evidence for contributions from urial and argali sheep. J Hered 89:113-120. https://doi.org/10. $1093 /$ jhered/89.2.113

Hole F (1996) The context of caprine domestication in the Zagros region. In: Harris DR (ed) The origins and spread of agriculture and pastoralism in Eurasia. UCL Press, London, pp 263-281

Hollemeyer K, Altmeyer W, Heinzle E, Pitra C (2012) Matrix-assisted laser desorption/ionization time-of-flight mass spectrometry combined with multidimensional scaling, binary hierarchical cluster tree and selected diagnostic masses improves species identification of Neolithic keratin sequences from furs of the Tyrolean iceman Oetzi rapid communications in mass spectrometry. RCM 26:17351745. https://doi.org/10.1002/rcm.6277 
Holst MK, Breuning-Madsen H, Rasmussen M (2001) The South Scandinavian barrows with well-preserved oak-log coffins. Antiquity 75:126-136. https://doi.org/10.1017/ S0003598X00052820

Horsburgh KA, Rhines A (2010) Genetic characterization of an archaeological sheep assemblage from South Africa's Western Cape. J Archaeol Sci 37:2906-2910. https://doi.org/10.1016/j.jas.2010.06. 035

Jonsson H, Ginolhac A, Schubert M, Johnson PL, Orlando L (2013) mapDamage 2.0: fast approximate Bayesian estimates of ancient DNA damage parameters. Bioinformatics (Oxford, England) 29: 1682-1684. https://doi.org/10.1093/bioinformatics/btt193

Kania K (2015) Soft yarns, hard facts? Evaluating the results of a largescale hand-spinning experiment. Archaeol Anthropol Sci 7:113130. https://doi.org/10.1007/s12520-013-0167-y

Kijas JW, Lenstra JA, Hayes B, Boitard S, Porto Neto LR, San Cristobal M, Servin B, McCulloch R, Whan V, Gietzen K, Paiva S, Barendse W, Ciani E, Raadsma H, McEwan J, Dalrymple B, other members of the International Sheep Genomics Consortium (2012) Genomewide analysis of the world's sheep breeds reveals high levels of historic mixture and strong recent selection. PLoS Biol 10: e1001258. https://doi.org/10.1371/journal.pbio.1001258

Killen JT (1964) The Wool Industry of Crete in the Late Bronze Age. The Annual of the British School at Athens 59:1-15. https://doi.org/10. 1017/S0068245400006031

Killien JT (2015) Economy and Administration in Mycenaean Greece. Collected papers on linear B. Incunabula Graeca CIV, vol 1-3. CNR - Istituto di Studi sul Mediterraneo Antico, Rome

Kristiansen K (2016) Interpreting Bronze Age trade and migration. In: Kiriatzi E, Knappett C (eds) Human mobility and technological transfer in the prehistoric Mediterranean. Cambridge Univeristy Press, Cambridge, pp 128-153

Kristiansen K, Sørensen MLS (in Press) Wool in the Bronze Age. Concluding reflections. In: Sabatini S, Bergerbrant S (eds) The Textile Revolution in Bronze Age Europe. Cambridge University Press, Cambridge,

Lancioni H, di Lorenzo P, Ceccobelli S, Perego UA, Miglio A, Landi V, Antognoni MT, Sarti FM, Lasagna E, Achilli A (2013) Phylogenetic relationships of three Italian merino-derived sheep breeds evaluated through a complete mitogenome analysis. PLoS One 8:e73712. https://doi.org/10.1371/journal.pone.0073712

Larson G, Albarella U, Dobney K, Rowley-Conwy P, Schibler J, Tresset A, Vigne JD, Edwards CJ, Schlumbaum A, Dinu A, Balacsescu A, Dolman G, Tagliacozzo A, Manaseryan N, Miracle P, van Wijngaarden-Bakker L, Masseti M, Bradley DG, Cooper A (2007) Ancient DNA, pig domestication, and the spread of the Neolithic into Europe. Proc Natl Acad Sci 104(39):15276-15281. https://doi. org/10.1073/pnas.0703411104

Larson G, Burger J (2013) A population genetic theory of animal domestication. Trends in Genetics 29(4):197-205

Larson G, Dobney K, Albarella U, Fang M, Matisoo-Smith E, Robins J, Lowden S, Finlayson H, Brand T, Willerslev E, Rowley-Conwy P, Andersson L, Cooper A (2005) Worldwide phylogeography of wild boar reveals multiple centers of pig domestication. Science (New York, NY) 307:1618-1621. https://doi.org/10.1126/science. 1106927

Larson G, Fuller DQ (2014) The evolution of animal domestication. Annu Rev Ecol Evol Syst 66:115-136. https://doi.org/10.1146/ annurev-ecolsys-110512-135813

Lawson Handley LJ, Byrne K, Santucci F, Townsend S, Taylor M, Bruford MW, Hewitt GM (2007) Genetic structure of European sheep breeds. Heredity 99:620-631. https://doi.org/10.1038/sj.hdy. 6801039

Lazaridis I, Nadel D, Rollefson G, Merrett DC, Rohland N, Mallick S, Fernandes D, Novak M, Gamarra B, Sirak K, Connell S, Stewardson K, Harney E, Fu Q, Gonzalez-Fortes G, Jones ER, Roodenberg SA,
Lengyel G, Bocquentin F, Gasparian B, Monge JM, Gregg M, Eshed V, Mizrahi AS, Meiklejohn C, Gerritsen F, Bejenaru L, Blüher M, Campbell A, Cavalleri G, Comas D, Froguel P, Gilbert E, Kerr SM, Kovacs P, Krause J, McGettigan D, Merrigan M, Merriwether DA, O'Reilly S, Richards MB, Semino O, ShamoonPour M, Stefanescu G, Stumvoll M, Tönjes A, Torroni A, Wilson JF, Yengo L, Hovhannisyan NA, Patterson N, Pinhasi R, Reich D (2016) Genomic insights into the origin of farming in the ancient Near East. Nature 536:419-424. https://doi.org/10.1038/ nature 19310

Legge T (1996) The beginning of caprine domestication in Southwest Asia. In: Harris DR (ed) The origins and spread of agriculture and pastoralism in Eurasia. UCL Press, London, pp 238-262

Li H, Durbin R (2009) Fast and accurate short read alignment with burrows-wheeler transform. Bioinformatics (Oxford, England) 25: 1754-1760. https://doi.org/10.1093/bioinformatics/btp324

Li H, Handsaker B, Wysoker A, Fennell T, Ruan J, Homer N, Marth G, Abecasis G, Durbin R, 1000 Genome Project Data Processing Subgroup (2009) The sequence alignment/map format and SAMtools. Bioinformatics (Oxford, England) 25:2078-2207. https://doi.org/10.1093/bioinformatics/btp352

Lindahl T (1993) Instability and decay of the primary structure of DNA. Nature 362:709-715. https://doi.org/10.1038/362709a0

Lindgreen S (2012) AdapterRemoval: easy cleaning of next-generation sequencing reads. BMC Research Notes 5:337. https://doi.org/10. 1186/1756-0500-5-337

Luikart G, Gielly L, Excoffier L, Vigne JD, Bouvet J, Taberlet P (2001) Multiple maternal origins and weak phylogeographic structure in domestic goats. Proc Natl Acad Sci 98(10):5927-5932. https://doi. org/10.1073/pnas.091591198

Marciniak A (2011) The secondary products revolution: empirical evidence and its current zooarchaeological critique. J World Prehist 24: 117-130. https://doi.org/10.1007/s10963-011-9045-7

Margaryan A, Derenko M, Hovhannisyan H, Malyarchuk B, Heller R, Khachatryan Z, Avetisyan P, Badalyan R, Bobokhyan A, Melikyan V, Sargsyan G, Piliposyan A, Simonyan H, Mkrtchyan R, Denisova G, Yepiskoposyan L, Willerslev E, Allentoft ME (2017) Eight millennia of matrilineal genetic continuity in the South Caucasus. Current Biology 27:2023-2028.e2027. https://doi.org/10.1016/j. cub.2017.05.087

Marić Baković M, Car G (2014) Konzervatorsko-restauratorski radovi I rezultati najnovijih analiza na tekstilnome plaštu is prapovijesnoga zemljanog tumula Br. 16 Pustopolje, Kupres. Cleuna 1:30-47

Matoïan V, Vita J-P (2014) Wool production and economy at Ugarit. In: Breniquet C, Michel C (eds) Wool economy in the ancient Near East and the Aegean: from the beginnings of sheep husbandry to institutional textile industry. Ancient Textiles Series, vol 17. Oxbow Books Ltd, Oxford, pp 310-339

Meadows JR, Hiendleder S, Kijas JW (2011) Haplogroup relationships between domestic and wild sheep resolved using a mitogenome panel. Heredity 106:700-706. https://doi.org/10.1038/hdy.2010.122

Meadows JR, Li K, Kantanen J, Tapio M, Sipos W, Pardeshi V, Gupta V, Calvo JH, Whan V, Norris B, Kijas JW (2005) Mitochondrial sequence reveals high levels of gene flow between breeds of domestic sheep from Asia and Europe. J Hered 96:494-501. https://doi.org/ 10.1093/jhered/esi100

Meadows JRS, Cemal I, Karaca O, Gootwine E, Kijas JW (2007) Five ovine mitochondrial lineages identified from sheep breeds of the near east. Genetics 175:1371-1379. https://doi.org/10.1534/ genetics.106.068353

Michel C, Nosch ML (eds) (2010) Textile terminologies in the ancient Near East and Mediterranean from the third to the first millennia BC. Ancient Textiles Series, vol 8. Oxbow Books Ltd, Oxford

Munro JH (2003) Medieval woollens: textiles, textile technology and industrial organization, c. 800-1500. In: Jenkins D (ed) The 
Cambridge history of western textiles, vol I. Cambridge University Press, Cambridge, pp 181-227

Naderi S, Rezaei HR, Pompanon F, Blum MGB, Negrini R, Naghash HR, Balkiz O, Mashkour M, Gaggiotti OE, Ajmone-Marsan P, Kence A, Vigne JD, Taberlet $\mathrm{P}$ (2008) The goat domestication process inferred from large-scale mitochondrial DNA analysis of wild and domestic individuals. Proc Natl Acad Sci 105(46):17659-17664. https://doi. org/10.1073/pnas.0804782105

Niemi M, Bläuer A, Iso-Touru T, Nyström V, Harjula J, Taavitsainen JP, Storå J, Lidén K, Kantanen J (2013) Mitochondrial DNA and Ychromosomal diversity in ancient populations of domestic sheep (Ovis aries) in Finland: comparison with contemporary sheep breeds. Genet Sel Evol 45:2. https://doi.org/10.1186/1297-968645-2

Nosch ML (2014) Mycenaean wool economies in the latter part of the 2nd millennium BC Aegean. In: Breniquet C, Michel C (eds) Wool economy in the ancient near east and the Aegean: from the beginnings of sheep husbandry to institutional textile industry. Ancient Textiles Series, vol 17. Oxbow Books Ltd, Oxford, pp 371-400

Nosch ML (2015) The wool age: traditions and innovations in textile production, consumption and administration in the Late Bronze Age Aegean. In: Weilhartner J, Ruppenstein F (eds) Tradition and innovation in the Mycenaean palatial polities. Austrian Academy of Science Press, Vienna, pp 167-201

O’Sullivan NJ, Teasdale MD, Mattiangeli V, Maixner F, Pinhasi R, Bradley DG, Zink A (2016) A whole mitochondria analysis of the Tyrolean Iceman's leather provides insights into the animal sources of Copper Age clothing. Sci Rep 6:31279. https://doi.org/10.1038/ srep31279

Olivieri C, Ermini L, Rizzi E, Corti G, Luciani S, Marota I, de Bellis G, Rollo F (2012) Phylogenetic position of a copper age sheep (Ovis aries) mitochondrial DNA. PLoS One 7:e33792. https://doi.org/10. 1371/journal.pone.0033792

Payne S (1973) Kill-off patterns in sheep and goats: the mandibles from Aşvan kale. Anatol Stud 23:281-303. https://doi.org/10.2307/ 3642547

Pedrosa S, Uzun M, Arranz J-J, Gutiérrez-Gil B, San Primitivo F, Bayón Y (2005) Evidence of three maternal lineages in near eastern sheep supporting multiple domestication events. Proc R Soc B Biol Sci 272:2211-2217. https://doi.org/10.1098/rspb.2005.3204

Pereira F, Davis SJ, Pereira L, McEvoy B, Bradley DG, Amorim A (2006) Genetic signatures of a Mediterranean influence in Iberian Peninsula sheep husbandry. Mol Biol Evol 23:1420-1426. https:// doi.org $/ 10.1093 / \mathrm{molbev} / \mathrm{ms} 1007$

Pipes ML, Kuuk J, Milisauskas S (2014) Assessing the archaeological data for wool-bearing sheep during the Middle to Late Neolithic at Bronocice, Poland. In: Greenfield HJ (ed) Animal Secondary Products: Domestic Animal Explotation in Prehistoric Europe, the Near East and the Far East. Oxbow Books Ltd, Oxford, pp 80-102

Rannamäe E, Lõugas L, Niemi M, Kantanen J, Maldre L, Kadõrova N, Saarma U (2016a) Maternal and paternal genetic diversity of ancient sheep in Estonia from the Late Bronze Age to the post-medieval period and comparison with other regions in Eurasia. Animal Genetics 47:208-218 doi:doi:https://doi.org/10.1111/age.12407

Rannamäe E, Lõugas L, Speller CF, Valk H, Maldre L, Wilczyński J, Mikhailov A, Saarma U (2016b) Three thousand years of continuity in the maternal lineages of ancient sheep (Ovis aries) in Estonia. PLoS One 11:e0163676. https://doi.org/10.1371/journal.pone. 0163676

Rast-Eicher A (2012) CinBA: wools from Sweden: fibre measurements. Report of fibre analysis preformed for the CinBA project. Unpublished Report ArcheoTex

Rast-Eicher A (2013) Experiment: wool measurement of samples spun by Lena Hammarlund. Unpublished Report ArcheoTex

Rast-Eicher A (2016) Fibres: microscopy of archaeological textiles and furs. Archaeolingua Alapítvány, Budapest
Rast-Eicher A, Bender Jørgensen L (2013) Sheep wool in Bronze Age and Iron Age Europe. J Archaeol Sci 40:1224-1241. https://doi.org/ 10.1016/j.jas.2012.09.030

Rougemont F (2014) Sheeprearing, wool production and management in Mycenaean written documents. In: Breniquet C, Michel C (eds) Wool economy in the ancient near east and the Aegean: from the beginnings of sheep husbandry to institutional textile industry. Ancient Textiles Series, vol. 17. Oxford Books Ltd, Oxford, pp 340-370

Ryder ML (1969) Changes in the fleeces of sheep following domestication. In: Ucko PJ, Dimbleby A, Dimbleby GW (eds) The domestication and exploitation of plants and animals. Routledge, London, pp 495-521

Ryder ML (1983) Sheep \& man. Duckworth, London

Ryder ML (1988) Danish bronze age wools. Journal of Danish Archaeology 7:136-143. https://doi.org/10.1080/0108464X.1988. 10590002

Sabatini S (2018) Wool economy during the European Bronze Age. Światowit 56:43-55. https://doi.org/10.5604/01.3001.0012.8457

Sabatini S, Earle T, Cardarelli A (2018) Bronze age textile and wool economy: the case of the Terramare site of Montale, Italy. Proceedings of the Prehistoric Society 84:359-385. https://doi.org/ 10.1017/ppr.2018.11

Salvagno L, Albarella U (2017) A morphometric system to distinguish sheep and goat postcranial bones. PLoS One 12:e0178543. https:// doi.org/10.1371/journal.pone.0178543

Schmölcke U, Gross D, Nikulina EA (2018) The history of sheep husbandry in Austria from the Neolithic to the Roman Period. Annalen des Naturhistorischen Museums in Wien, Serie A 120:101-126

Schröder O, Wagner M, Wutke S, Zhang Y, Ma Y, Xu D, Goslar T, Neef R, Tarasov PE, Ludwig A (2016) Ancient DNA identification of domestic animals used for leather objects in Central Asia during the Bronze Age. The Holocene 26:1722-1729. https://doi.org/10. 1177/0959683616641741

Schubert M, Ginolhac A, Lindgreen S, Thompson JF, AL-Rasheid KAS, Willerslev E, Krogh A, Orlando L (2012) Improving ancient DNA read mapping against modern reference genomes. BMC Genomics 13:e178. https://doi.org/10.1186/1471-2164-13-178

Seroussi E, Rosov A, Shirak A, Lam A, Gootwine E (2017) Unveiling genomic regions that underlie differences between Afec-Assaf sheep and its parental Awassi breed. Genet Sel Evol 49:e19. https://doi. org/10.1186/s12711-017-0296-3

Sherratt A (1981) Plough and pastoralism: aspects of the secondary products revolution. In: Hodder I, Isaac G, Hammond N (eds) Pattern of the past. Cambridge University Press, Cambridge, pp 261-305

Sherratt A (1983) The secondary exploitation of animals in the Old World. World Archaeol 15:90-104. https://doi.org/10.1080/ 00438243.1983 .9979887

Shislina NI, Orfinskaya OV, Golikov VP (2003) Bronze Age Textiles from the North Caucasus: new Evidence of Fourth Millenium BC Fibres and Fabrics. Oxford Journal of Archaeology 22:331-344

Siennicka M (2014) Changes in textile production in Late Bronze Age Tiryns, Greece. In: Droß-Krüpe K (ed) Textile trade and distribution in antiquity. Harrassowitz Verlag, Wiesbaden, pp 163-176

Sinding M-HS, Vieira FG, Smith MH (2017) Unmatched DNA preservation prove arctic hare and sheep wool in Norse Greenlandic textile from "the farm beneath the sand". J Archaeol Sci Rep 14:603-608. https://doi.org/10.1016/j.jasrep.2017.06.043

Skals I (in press) To let textiles talk: fibre identification and technological analyses of prehistoric textiles from Denmark. In: Sabatini S, Bergerbrant S (eds) The Textile Revolution in Bronze Age Europe. Cambridge University Press, Cambridge

Skals I, Gleba M, Taube M, Mannering U (2018) Wool textiles and archaeometry: testing reliability of archaeological wool fibre diameter measurements. Danish Journal of Archaeology 7:161-179. https://doi.org/10.1080/21662282.2018.1495917 
Skals I, Möller-Wiering S, Nosch ML (2015) Survey of archaeological textile remains from the Aegean and Eastern Mediterranean Area. In: Andersson Strand E, Nosch ML (eds) Tools, textiles and contexts: textile production in the Aegean and Eastern Mediterranean Bronze Age. Ancient Textiles Series, vol 21. Oxbow Books Ltd, Oxford, pp 61-74

Skoglund P, Posth C, Sirak K, Spriggs M, Valentin F, Bedford S, Clark GR, Reepmeyer C, Petchey F, Fernandes D, Fu Q, Harney E, Lipson M, Mallick S, Novak M, Rohland N, Stewardson K, Abdullah S, Cox MP, Friedlaender FR, Friedlaender JS, Kivisild T, Koki G, Kusuma P, Merriwether DA, Ricaut FX, Wee JTS, Patterson N, Krause J, Pinhasi R, Reich D (2016) Genomic insights into the peopling of the Southwest Pacific. Nature 538:510-513. https:// doi.org/10.1038/nature19844

Stiner MC, Buitenhuis H, Duru G, Kuhn SL, Mentzer SM, Munro ND, Pöllath N, Quade J, Tsartsidou G, Özbaşaran M (2014) A foragerherder trade-off, from broad-spectrum hunting to sheep management at Asikli Hoyuk, Turkey. Proc Natl Acad Sci 111(23):8404-8409. https://doi.org/10.1073/pnas.1322723111

Tapio M, Marzanov N, Ozerov M, Ćinkulov M, Gonzarenko G, Kiselyova T, Murawski M, Viinalass H, Kantanen J (2006) Sheep mitochondrial DNA variation in European, Caucasian, and central Asian areas. Mol Biol Evol 23:1776-1783. https://doi.org/10.1093/ molbev/ms1043

Thomsen E, Andreasen R (2019) Agricultural lime disturbs natural strontium isotope variations: implications for provenance and migration studies. Sci Adv 5:eaav8083. https://doi.org/10.1126/sciadv. aav8083

Tournavitou I, Andersson Strand E, Louise NM, Cutler J (2015) Textile tools at Mycenae, mainland Greece. In: Andersson Strand E, Nosch ML (eds) Tools, textiles and contexts: textile production in the Aegean and Eastern Mediterranean Bronze Age. Ancient Textiles Series, vol 21. Oxbow Books Ltd, Oxford, pp 253-262

Waetzoldt H (1972) Untersuchungen zur neusumerischen Textilindustrie. Centro per le antichità e la storia dell'arte del Vicino Oriente, Roma
Wang H, Zhang L, Cao J, Wu M, Ma X, Liu Z, Liu R, Zhao F, Wei C, du $\mathrm{L}$ (2015) Genome-wide specific selection in three domestic sheep breeds. PLoS One 10:e0128688. https://doi.org/10.1371/journal. pone. 0128688

Vicze M (2013) Expecting the unexpected: Szàzhalombatta-Földvàr surprises once again. In: Bergerbrant S, Sabatini S (eds) Counterpoint: essays in archaeology and cultural heritage in honour to professor Kristian Kristiansen. Archaeopress, Oxford, pp 71-76

Willerslev E, Cooper A (2005) Ancient DNA. Proceedings of the Royal Society, Biological sciences 272:3-16 https://doi.org/10.1098/rspb. 2004.2813

Wisti Lassen A (2010) The trade on wool in old Assyrian Anatolia. Jaarbericht Ex Oriente Lux 42:159-179

Wood NJ, Phua SH (1996) Variation in the control region sequence of the sheep mitochondrial genome. Anim Genet 27:25-33. https://doi. org/10.1111/j.1365-2052.1996.tb01173.x

Vretemark M (2010) Subsistence strategies. In: Earle T, Kristiansen K (eds) Organizing Bronze Age societies; the Mediterranean, Central Europe, and Scandinavia compared. Cambridge University Press, Cambridge, pp 155-184

Zeder MA (2012) The domestication of animals. J Anthropol Res 68: 161-190. https://doi.org/10.3998/jar.0521004.0068.201

Zilhão J (2001) Radiocarbon evidence for maritime pioneer colonization at the origins of farming in west. Mediterranean Europe Proc Natl Acad Sci 98(24):14180-14185. https://doi.org/10.1073/pnas. 241522898

Publisher's note Springer Nature remains neutral with regard to jurisdictional claims in published maps and institutional affiliations. 